\title{
Pyramidal cell development: postnatal spinogenesis, dendritic growth, axon growth, and electrophysiology
}

\author{
Guy N. Elston ${ }^{1 *}$ and Ichiro Fujita ${ }^{2}$ \\ ${ }^{1}$ Centre for Cognitive Neuroscience, Sunshine Coast, OLD, Australia \\ ${ }^{2}$ Graduate School of Frontier Biosciences and Center for Information and Neural Networks, Osaka University and National Institute of Communication Technology, \\ Suita, Japan
}

Edited by:

Ruth Benavides-Piccione, Cajal

Institute, Spain

\section{Reviewed by:}

Marco Aurelio M. Freire, Edmond and Lily Safra International Institute for Neurosciences of Natal, Brazil

Jennifer Irene Luebke, Boston

University, USA

*Correspondence:

Guy N. Elston, Centre for Cognitive Neuroscience, 60 Duke Rd.,

Doonan, Sunshine Coast,

QLD 4562, Australia

e-mail: guyelston@yahoo.com
Here we review recent findings related to postnatal spinogenesis, dendritic and axon growth, pruning and electrophysiology of neocortical pyramidal cells in the developing primate brain. Pyramidal cells in sensory, association and executive cortex grow dendrites, spines and axons at different rates, and vary in the degree of pruning. Of particular note is the fact that pyramidal cells in primary visual area (V1) prune more spines than they grow during postnatal development, whereas those in inferotemporal (TEO and TE) and granular prefrontal cortex (gPFC; Brodmann's area 12) grow more than they prune. Moreover, pyramidal cells in TEO, TE and the gPFC continue to grow larger dendritic territories from birth into adulthood, replete with spines, whereas those in V1 become smaller during this time. The developmental profile of intrinsic axons also varies between cortical areas: those in V1, for example, undergo an early proliferation followed by pruning and local consolidation into adulthood, whereas those in area TE tend to establish their territory and consolidate it into adulthood with little pruning. We correlate the anatomical findings with the electrophysiological properties of cells in the different cortical areas, including membrane time constant, depolarizing sag, duration of individual action potentials, and spike-frequency adaptation. All of the electrophysiological variables ramped up before 7 months of age in V1, but continued to ramp up over a protracted period of time in area TE. These data suggest that the anatomical and electrophysiological profiles of pyramidal cells vary among cortical areas at birth, and continue to diverge into adulthood. Moreover, the data reveal that the "use it or lose it" notion of synaptic reinforcement may speak to only part of the story, "use it but you still might lose it" may be just as prevalent in the cerebral cortex.

Keywords: synaptogenesis, axon, dendrite, spine, bouton, cortex, human, macaque

\section{INTRODUCTION}

Two opposing theories on postnatal synaptogenesis have dominated over the past two and a half decades. One theory posits that circuitry in all cortical areas matures concurrently (Rakic et al., 1986), whereas the other states that circuitry in different cortical areas mature at different rates (Huttenlocher and Dabholkar, 1997). Both theories have been derived from electronmicroscopic study of the cortical neuropil. In the former hypothesis, the maximum synaptic connectivity is achieved at approximately three and a half months of age, after which there is a net reduction in the number of synaptic connections in cortex (Figure 1). Data were sampled from visual (V1), somatosensory (SI), motor (M1) and prefrontal cortices. In the latter hypothesis, synaptic density in the neuropil may continue to increase over an extended period of time (Figure 2). Data were sampled from V1, auditory (A1) and granular prefrontal cortex (middle frontal gyrus). On the face of it, these hypotheses appear to be irreconcilable. However, these two theories were based on data obtained from different species, data leading to the former view were obtained from the macaque monkey whereas those supporting the later view were obtained from the human brain. Furthermore, these data were sampled from a select few cortical areas, and were not corrected for cell death, changes in myelination nor cortical growth (see Guillery, 2005 for a review). More recent studies, which accounted for changes in myelination and blood vessels, revealed laminar differences in the developmental profiles of synaptogenesis (Bourgeois et al., 1989; Huttenlocher, 1990; Zecevic and Rakic, 1991; Bourgeois and Rakic, 1993; Granger et al., 1995), but do not reconcile the different theories.

A number of other groups have investigated the issue by using a different approach-that of studying the growth of the dendritic trees of neurons. The results are less clear cut than the above interpretations, and vary with neuron type, cortical layer and cortical area. For example, Lund and colleagues, by studying thalamocortial recipient neurons in V1 of the macaque monkey, concluded that dendritic growth is not concurrent (temporally coincident) in different populations of cells, but, rather, there is a temporal disjoin between neurons in the magno- and 

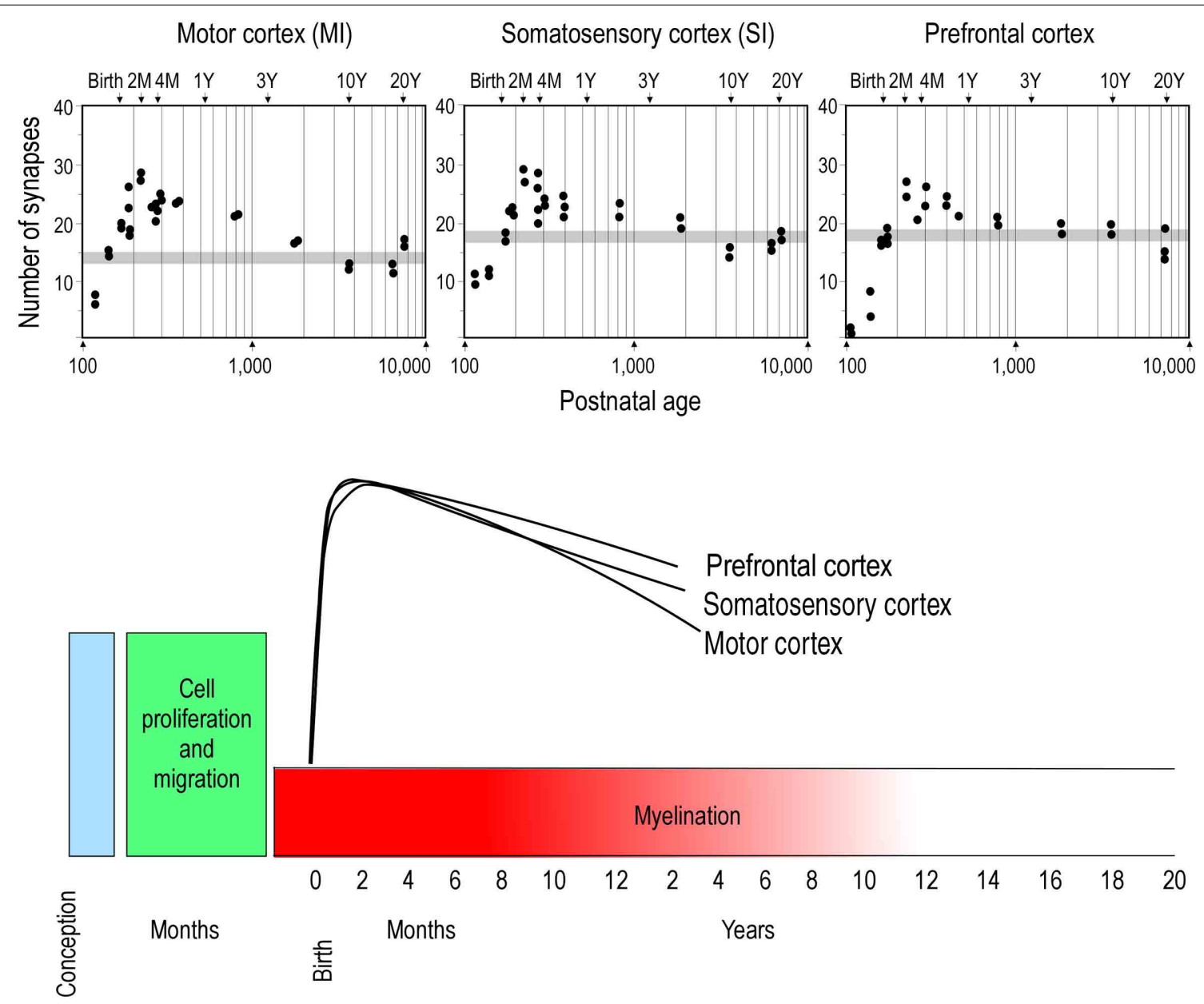

FIGURE 1 | Concurrent synaptogenesis. Plots illustrating the density of synapses per $100 \mu \mathrm{m}$ of cortical neuropil in the primary motor (MI) and somatosensory (SI) areas and ventrolateral prefrontal cortex (Brodmann's area 12) of the macaque monkey. The average synaptic density observed in the adult in each cortical area is represented by gray stipple. Note that in all cortical areas the maximum synapse density is recorded at approximately 2 months of age. Modified from Rakic et al. (1986). parvocellular pathways (Lund and Holbach, 1991). Moreover, the study revealed that the basal dendritic trees of pyramidal cells in V1 may continue to grow up to 9 months of age, despite a general trend for a decrease in the number of dendritic spines, the site of excitatory synaptic inputs, after 2 months of age (Boothe et al., 1979; Mates and Lund, 1983a,b). O'Kusky and Colonnier (1982) reported an increase in neuronal connectivity (as revealed by relative neuronal density, synaptic density and cortical thickness) from birth to 6 months of age in V1 of the macaque monkey, being most pronounced in supragranular layers. Becker et al. (1984) reported progressive dendritic growth and branching in the dendritic trees of supragranular pyramidal cells from conception until 2 years of age in human V1. Data reported at 2 years of age was greater than that reported in adults, but, it is difficult to determine at what age the dendritic trees stopped growing and began to retract to the size reported in the adult. Cupp and Uemura (1980) reported continued dendritic growth in pyramidal cells in the superior frontal gyrus of the macaque monkey up to 28 years of age. Koenderink et al. (1994) suggest continued growth of the dendritic trees of infragranular pyramidal cells up to at least 15 years of age in the human gPFC. Studies in the human and chimpanzee cortex reveal postnatal growth of the dendritic trees of pyramidal cells in the gPFC outstrip those in V1: in both species the dendritic trees of cells in the gPFC are small and sparsely branched at birth compared to those in $\mathrm{V} 1$, whereas in the adult they are markedly larger and more branched (Travis et al., 2005; Bianchi et al., 2012, 2013). Despite the variability in the results, the current view is that dendritic trees of some neurons may continue to grow well beyond the peak in synaptogenesis. The variability may reflect the different cortical areas, and species, that have been studied.

While the studies of dendritic growth provide significant insights into how the developmental profiles of neurons may vary among cortical areas, they are difficult to interpret because one must compare data sampled from one cortical area of a given species with another cortical area of a different species, or from one cortical layer with another. In addition, all of these studies 

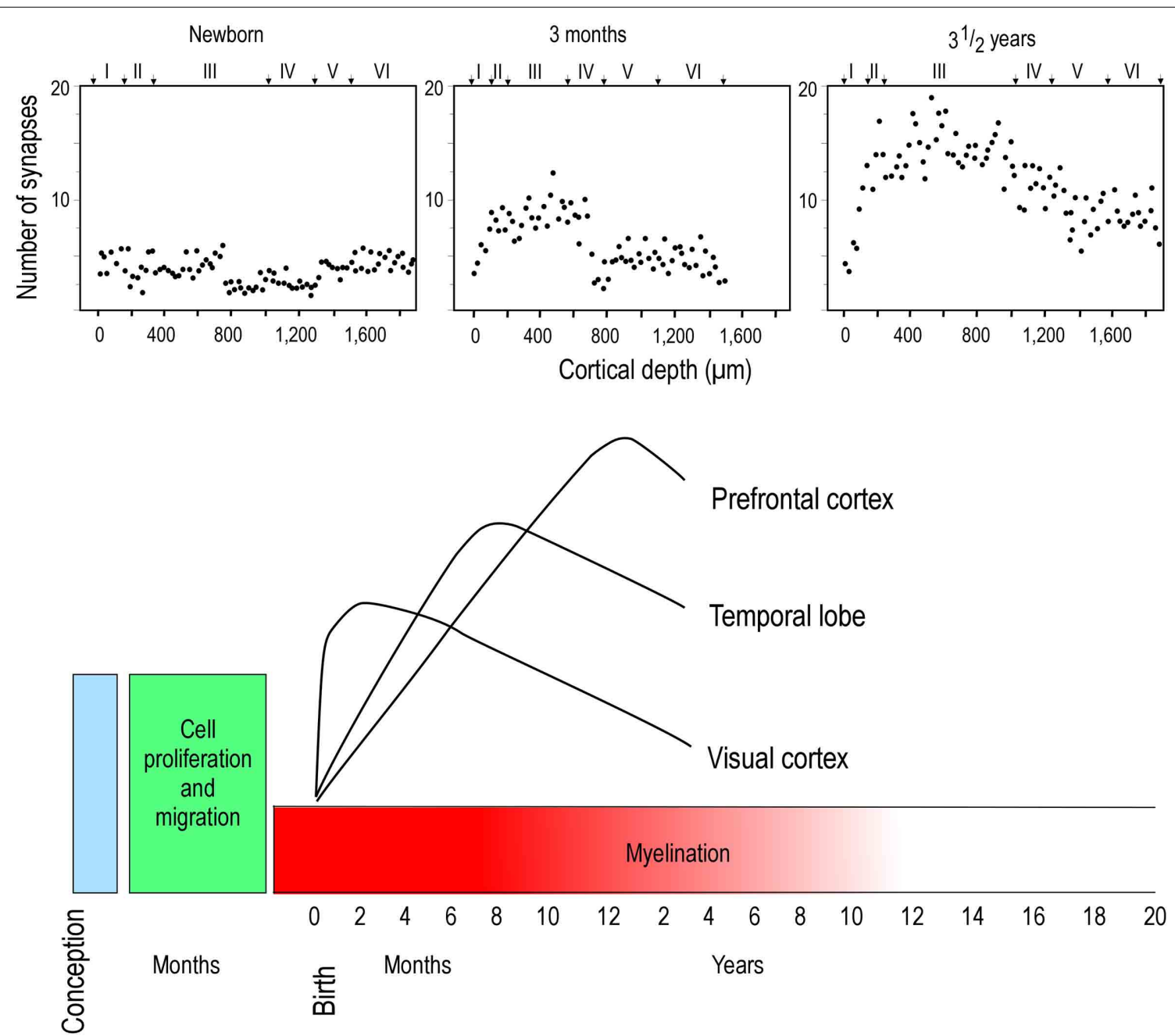

FIGURE 2 | Hierarchical synaptogenesis. Plots illustrating the density of synapses per $100 \mu \mathrm{m}$ of cortical neuropil in human left middle frontal gyrus in the newborn, 3 month old and in the three and a half year old postnatal brain. Note that the maximum synapse density at three and a half years of age is greater than that at 3 months of age. Note also the relative differences in synapse densities in the different cortical layers at the different ages illustrated. Modified from Huttenlocher and Dabholkar (1997). relied on the use of Golgi method. As discussed elsewhere (Elston et al., 2011b), this methodology only allows reconstruction of part of the dendritic tree (Figure 3). To visualize the entire basal dendritic tree of pyramidal cells in the human temporal lobe, for example, the sections would have to be at least $600 \mu \mathrm{m}$ thick. Even then, only neurons with their cell body located some $300 \mu \mathrm{m}$ into the section could be included for analyses otherwise some dendrites would be clipped (cf. Elston et al., 2001). Thus, while the Golgi method has been used to great effect for more than 100 years and it is fair to say that the field of neuroanatomy was built on this methodology (e.g., refer to the works of Santiago Ramon y Cajal, Karl Retzius, J LeRoy Conel, and Jennifer Lund to mention a few) and is still being used to great effect (e.g., Jacobs et al., 1997, 2001, 2014; Travis et al., 2005; Petanjek et al., 2008; Bianchi et al., 2012, 2013), a different approach was needed to test for area-specific differences in pyramidal cell structure.

\section{A DIFFERENT WAY OF LOOKING AT IT}

Intracellular injection of neurons in slices cut tangential to the cortical surface allows the visualization of the entire basal dendritic tree of large numbers of individual cells $(>1000)$ in a single brain allowing an uninterrupted reconstruction of even the longest dendrites (Figure 4) that may project more than $300 \mu \mathrm{m}$ from the cell body (e.g., Elston et al., 2001) yielding sufficient data to allow robust statistical comparisons. Neurons can be injected randomly, or specific populations of cells can be injected, such as corticocortical projecting or subcortical projecting cells (Vercelli and Innocenti, 1993; Matsubara et al., 1996; Elston and Rosa, 2006). In addition, all of the spines along a dendrite can be visualized with the aid of a high power objective and there is no need to attempt to correct for spines hidden by the Golgi precipitate (e.g., Feldman and Peters, 1979) as the DAB precipitate is less electron dense than the Golgi precipitate and the viewer is able to focus through the $\mathrm{DAB}$ precipitate under intense illumination 


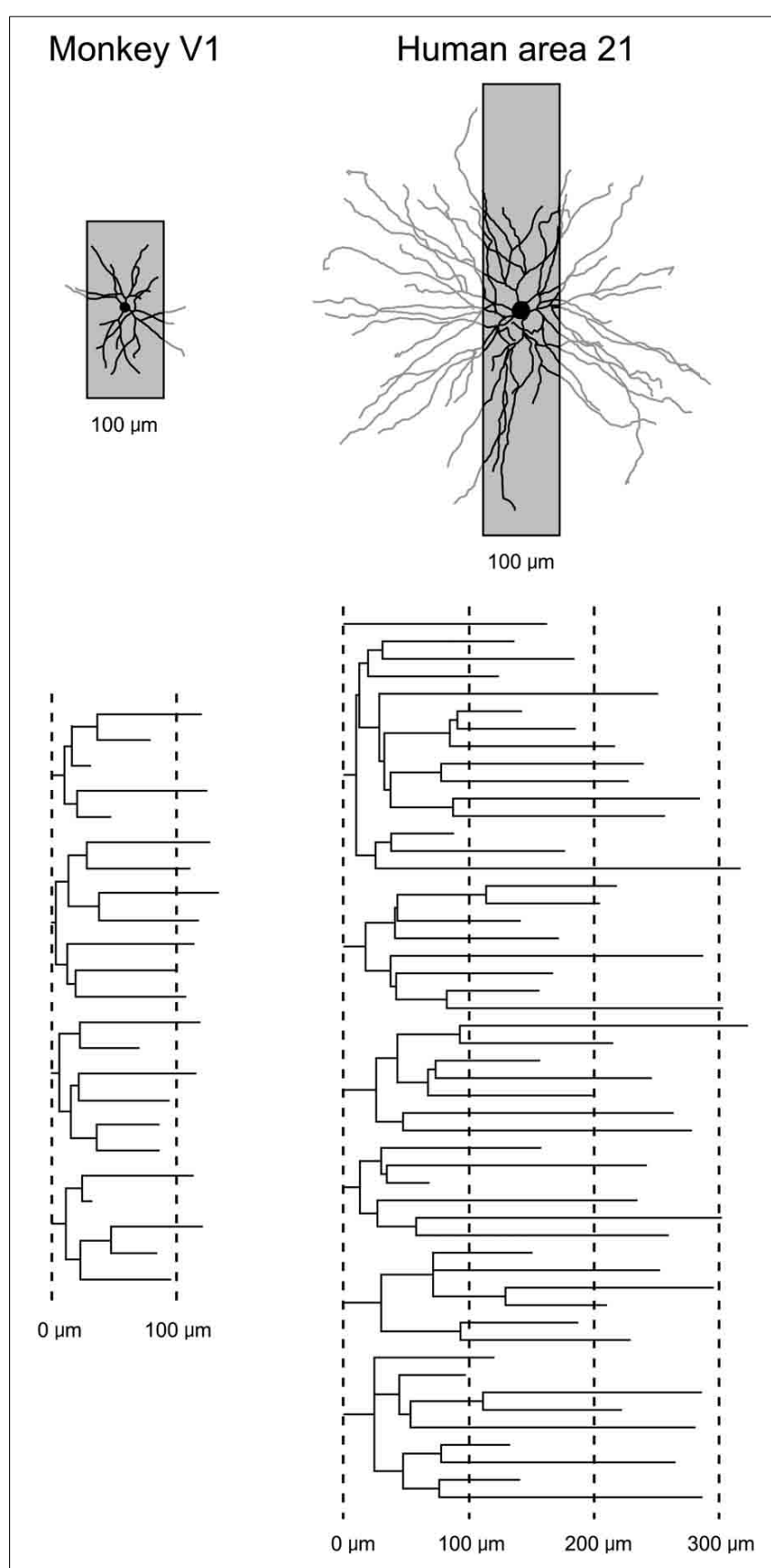

FIGURE 3 | Transverse vs. tangential plane. Schematic illustrating how the study of pyramidal cell morphology in the transverse plane may bias for uniformity in structure. Illustrated are two cells sampled from the primary visual area (V1) of the macaque monkey and Brodmann's area 21 of the temporal lobe of human (Brodmann, 1909). The basal dendritic trees of the two cells are shown in the tangential plane. Superimposed on each cell is a $100 \mu \mathrm{m}$ gray box representing the thickness of section routinely used in Golgi studies. In black is the part of the dendritic tree that would be seen in a Golgi study. In gray is the part of the dendritic tree that would have been clipped off during sectioning and thus invisible to the observer. Below are illustrated the dendrograms of each of the two cells, which resulted from reconstruction of the complete basal dendritic tree as seen in the tangential plane. Based on our observations in the human temporal lobe (Elston et al., 2001), transverse sections used in Golgi studies would have to be $>600 \mu \mathrm{m}$ thick, and the cell body located in the center of the section, to be able to visualize all dendrites.
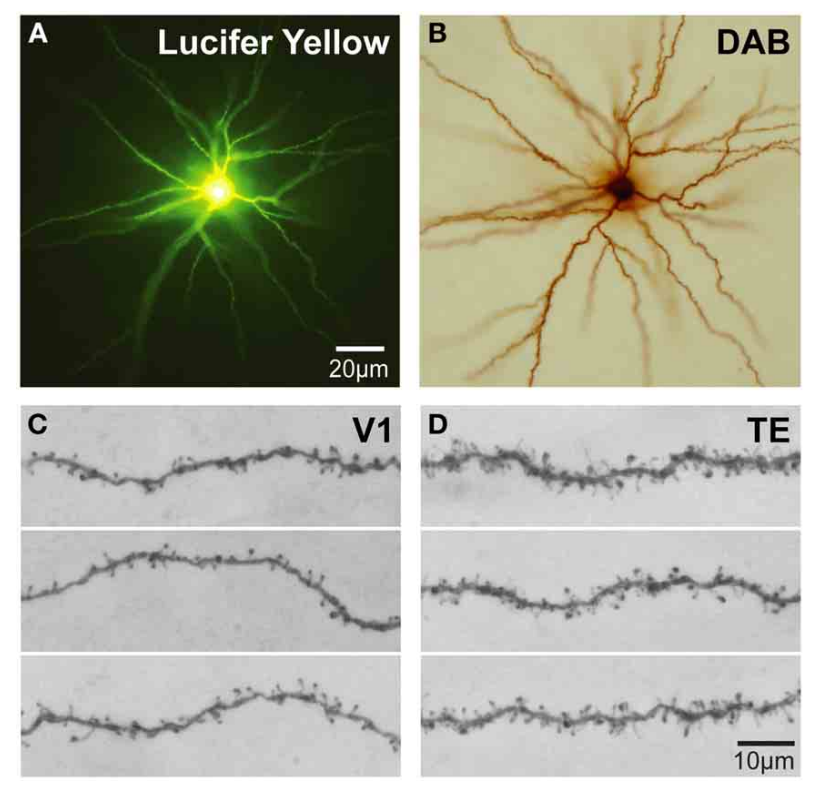

FIGURE 4 | Cell injection. (A) Low power photomicrographs of Lucifer Yellow-injected layer III pyramidal cells that were injected in tangential sections taken from the granular prefrontal cortex of the macaque monkey (area 12vl) and processed for a DAB reaction product. (B) (C,D) Higher power photos of primary visual (V1) and inferotemporal (TE) cortical cells as viewed through a $\times 100$ oil-immersion Zeiss objective, revealing aspects of their fine structure including dendritic spines. Scale bar $=20 \mu \mathrm{m}$ in $(\mathbf{A}, \mathbf{B})$ and $10 \mu \mathrm{m}$ in (C,D).

by standard light microscopy (see Elston and Rosa, 1997 for a discussion). Over the past 10 years we have applied this methodology to the study of pyramidal cell development in the cerebral cortex.

\section{DENDRITIC GROWTH IN POSTNATAL DEVELOPMENT}

The application of the cell injection method in flat-mount sections taken from the macaque monkey revealed systematic differences in the growth profiles of pyramidal cells among cortical areas (Figure 5). Notably, the basal dendritic trees of supragranular pyramidal cells continue to grow into adulthood in high level cortical areas such as visual association areas TEO, and TEpd whereas those in V1 attain their greatest postnatal size around birth (Boothe et al., 1979; Elston et al., 2010a). In granular prefrontal cortex (Brodmann's area 12), the basal dendritic trees of layer III pyramidal cells attain their largest size in adulthood (Elston et al., 2009; see also Cupp and Uemura, 1980; Anderson et al., 1995). The dendritic trees of pyramidal cells in V2 and V4 attain their greatest size at 3.5 months of age, and then decrease in size to their adult type (Elston et al., 2010a). A different profile again has been reported for cells in the primary auditory cortex (A1) in macaque, where cells grow larger dendritic trees from birth until at least 7 months of age, before decreasing in size to their adult form (Elston et al., 2010b).

Comparison of these data with previous Golgi data, and emerging cell injection data in other species, reveals potential species differences in the postnatal growth profiles of pyramidal cells in the cerebral cortex. The trend observed here in pyramidal cell growth in V1 of the macaque monkey is consistent with that 


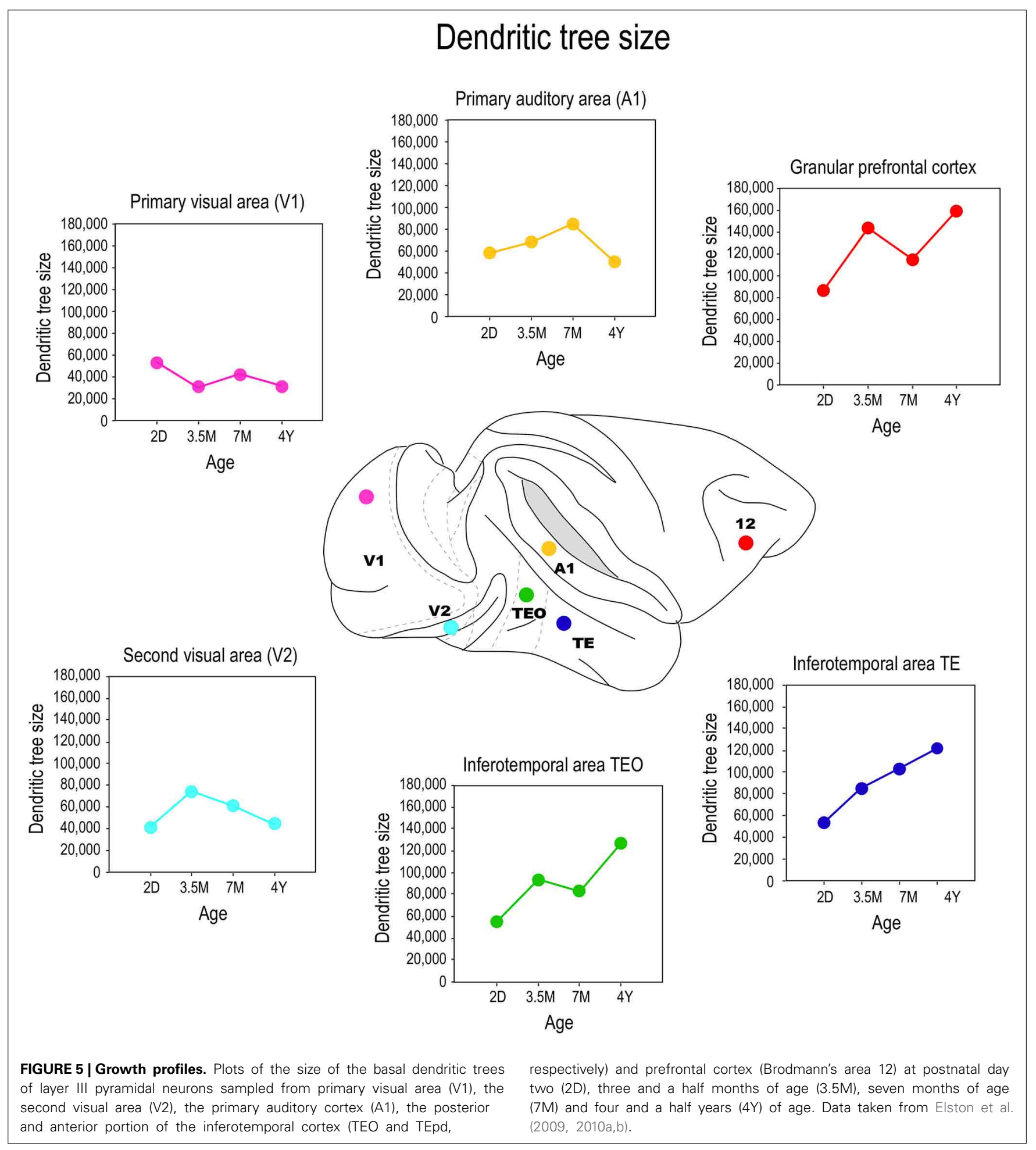

reported in human: cells become smaller after birth (Becker et al., 1984). The extended period of growth of the dendritic trees of cells in association areas of the temporal lobe and the granular prefrontal cortex in macaque is consistent with that reported in human (Conel, 1941, 1947, 1955, 1959, 1963, 1967; Elston et al., 2009, 2010a,b, 2011a). However studies in the New World marmoset monkey reveal that pyramidal cells in V1 are larger in the adult than in the newborn (Oga et al., 2013). Clearly, further comparative investigations are required.

\section{BRANCHING}

Differences were also observed in the branching profiles of the dendritic trees of pyramidal cells among cortical areas during postnatal development (Figure 6). Contrary to what might be 


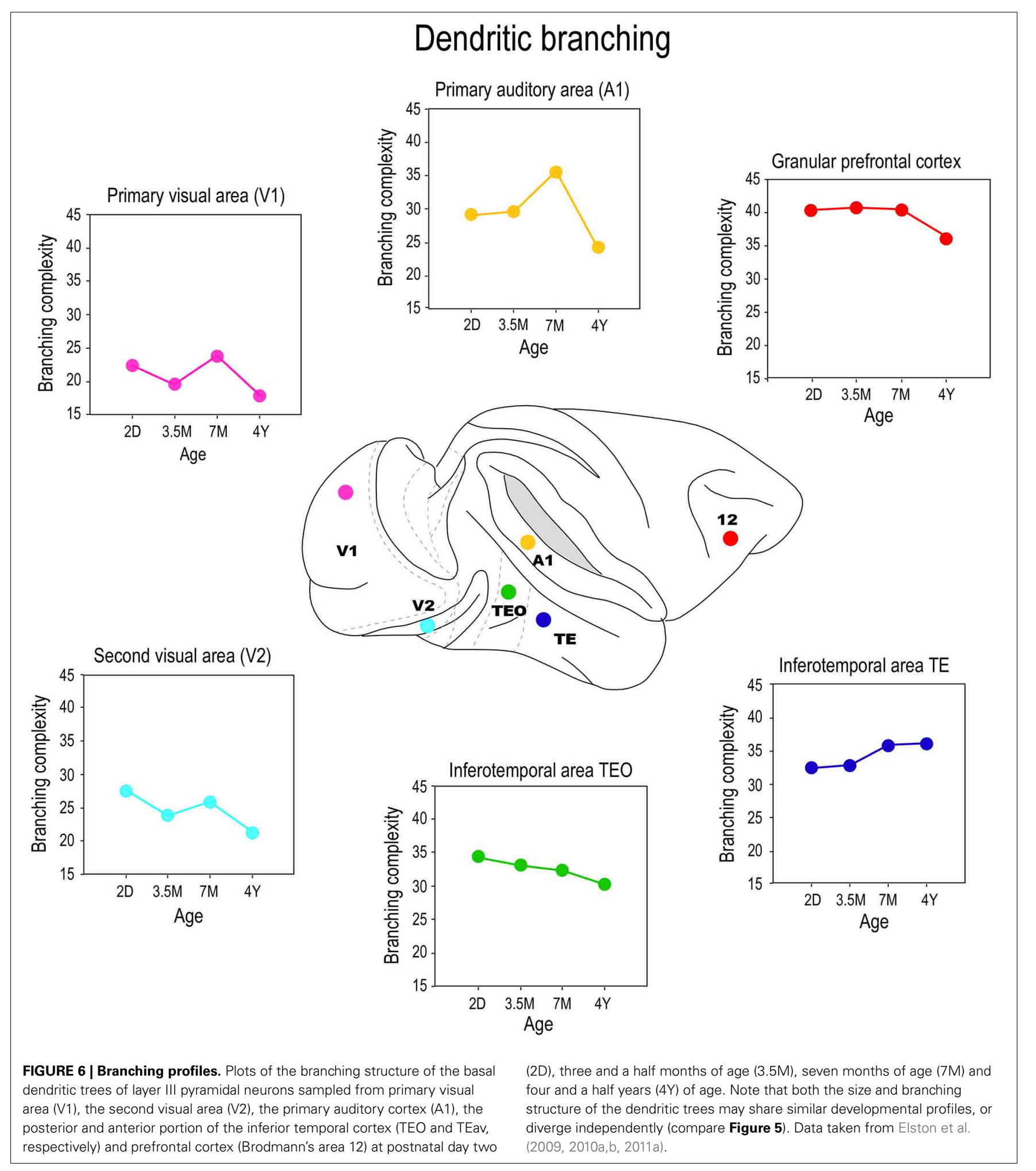

expected from the size, the dendritic trees of layer III pyramidal cells in area TEO of the macaque monkey were most branched at birth, and became less branched through juvenile and adolescent stages into adulthood (Elston et al., 2010a). In V1, V2, and V4, the most branched dendritic trees were observed at
PND2 and the least branched dendritic trees were observed in the adult (Elston et al., 2010a). In A1, the dendritic trees of layer III pyramidal cells became increasingly more branched from PND2 to 3.5-7 months of age before declining to their adult values (Elston et al., 2010b). Cells in granular prefrontal area 


\section{Dendritic spines}

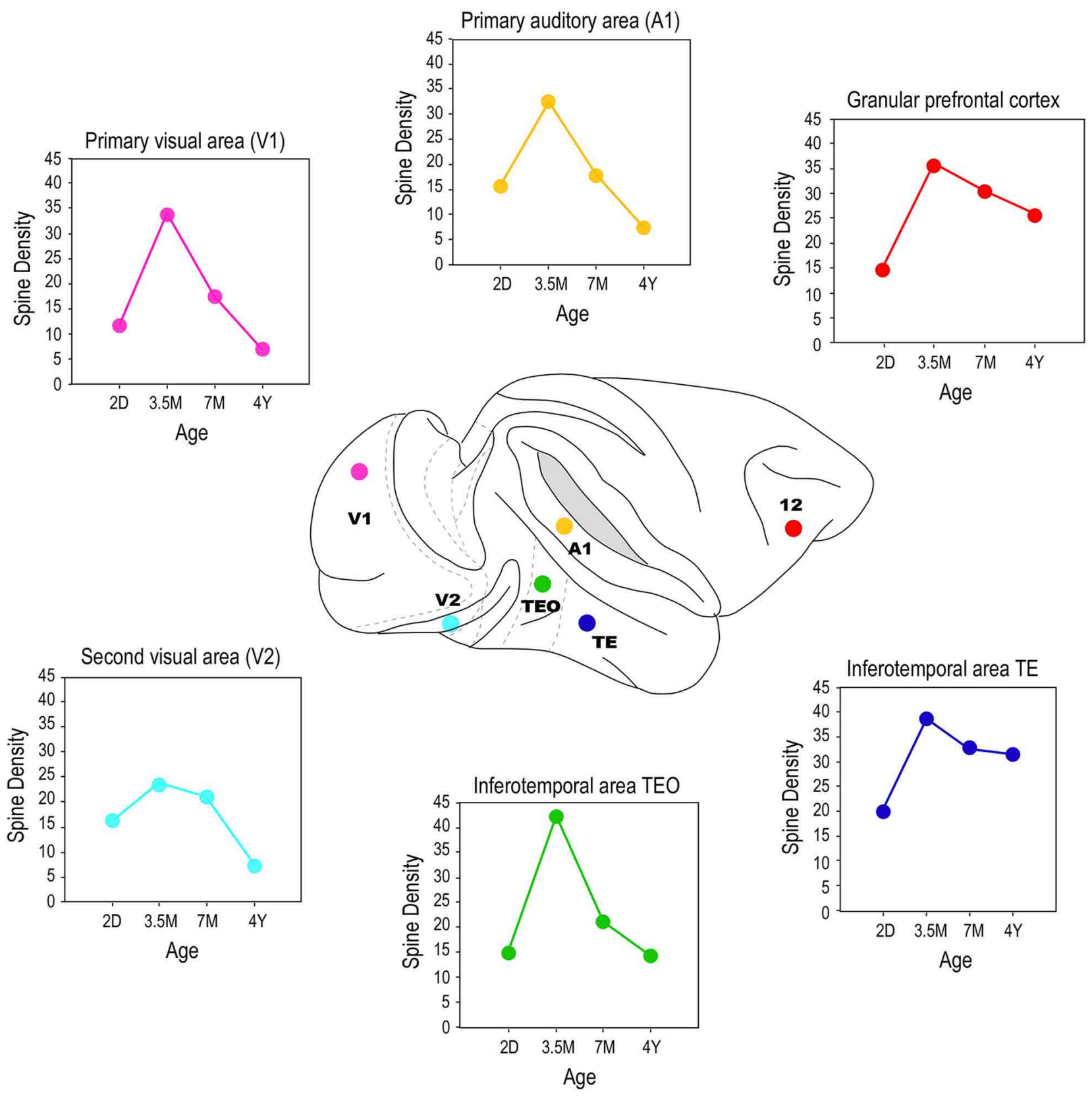

FIGURE 7 | Spinogenesis. Plots of the peak spine density (defined as the average of the maximum spine density observed in all $10 \mu \mathrm{m}$ segments of dendrite from the soma to the distal tips of the dendrites of all cells quantified for any given age) of layer III pyramidal cells sampled in the primary visual area (V1), the second visual area (V2), the primary auditory area (A1), the posterior and anterior portion of the inferior temporal cortex (TEO and TE, respectively) and prefrontal cortex (Brodmann's area 12) at postnatal day two (2D), three and a half months of age (3.5M), seven months of age (7M) and adults (AD). Note that in $\mathrm{V} 1, \mathrm{~V} 2$, and $\mathrm{A} 1$ there is a net reduction in the number of spines in the dendritic trees of pyramidal cells from birth to adulthood whereas in TEO, TE and area 12 there is a net increase in the number of spines over the same period. That is to say, the total number of spines grown in $\mathrm{V} 1, \mathrm{~V} 2$, and $\mathrm{A} 1$ following the onset of sensory experience is, on balance, lost with increasing sensory experience, but is stabilized, to varying degrees, with increasing associative and executive function in TEpd, TEav and area 12. Data taken from Elston et al. (2009, 2010a,b, 2011a).
12 , on the other hand, have relatively stable branching structure from birth to adolescence, then become less branched into adulthood, whereas those in area 46 become increasingly more branched from birth to $>4.5$ years of age (Anderson et al., 1995).
While seemingly contradictory, pyramidal cells in different areas within the mature gPFC of the macaque differ in size, branching structure and spine densities (Elston et al., 2011a). In the marmoset monkey, pyramidal cells in V1, TE, and area 12 are 
more branched in the adult than in the newborn (Oga et al., 2013).

These data make it tolerably clear that mechanisms that modulate postnatal dendritic growth and dendritic branching are not inextricably coupled in situ. For example, although the dendritic trees of pyramidal cells in V1 of the macaque were at their largest at 2D, they were most branched at 3 weeks of age. Cells in TEO and posterior TEpd in the macaque attain their greatest branching complexity at 3 weeks and 7 months of age, respectively, yet these cells are characterized by continual dendritic growth from PND2 to adulthood (Elston et al., 2010a). Cells in TEav are most branched in the adult, but attain their greatest size at 7 months of age (Elston et al., 2011b). Moreover, the mechanisms modulating growth and branching may exert their influence for different periods of time in different cortical areas. For example, in V2 the greatest branching complexity was observed in the dendritic trees at 3 weeks of age, whereas in V4 the greatest branching complexity occurred at 31/2 months of age (Elston et al., 2010a). In A1 the greatest branching complexity was observed at 7 months of age (Elston et al., 2010b). Growth of the dendritic tree and branching also show a degree of disjoin in the marmoset monkey: pyramidal cells in TE and area 12, in particular, are characterized by a marked increase in branching complexity from 2 months to 4.5 years of age while there is only a modest increase in the size of the trees during this same time (Oga et al., 2013). Recent detailed studies of pyramidal cell development in rodent somatosensory cortex also reveal different temporal profiles for growth, branching and spinogenesis (Romand et al., 2011). The authors found fast growth during the early postnatal period and the slow localized growth at latter ages, which they interpret as supporting functional compartmental development. Indeed, different compartments within the dendritic trees of pyramidal cells were shown to grow independently of each other (Romand et al., 2011).

\section{SPINOGENESIS}

By injecting cells in thick cortical slices, cut in the tangential plane, it is possible to reconstruct the entire basal dendritic trees of individual neurons. Thus, it is possible to draw and tally spines along the entire extent of dendrites, from the cell bodies to the distal tips, and determine the spine density as a function of distance from the soma (Eayrs and Goodhead, 1959; Valverde, 1967; Elston, 2001). Consistent with Pasco Rakic's findings for synapses (1986), we found that maximum peak spine density (defined as the average of the maximum spine density observed in all $10 \mu \mathrm{m}$ segments of dendrite from the soma to the distal tips of the dendrites of all cells quantified for any given age) was greatest in all cortical areas at approximately 3.5 months (Figure 7). The maximum peak spine density among cells in the different cortical areas were remarkably similar at 3.5 months of age (approximately 30 spines per 10 micrometers). However, the rate of spine loss in the dendritic trees of pyramidal cells in the different cortical areas varies considerably such that those in $\mathrm{V} 1$, for example, prune to a maximum peak spine density of approximately 6 spines per 10 micrometers whereas those in the gPFC prune to a peak of approximately 25 spines per 10 micrometers. Likewise, the maximum peak spine density was observed at approximately 3.5 months of age in the marmoset

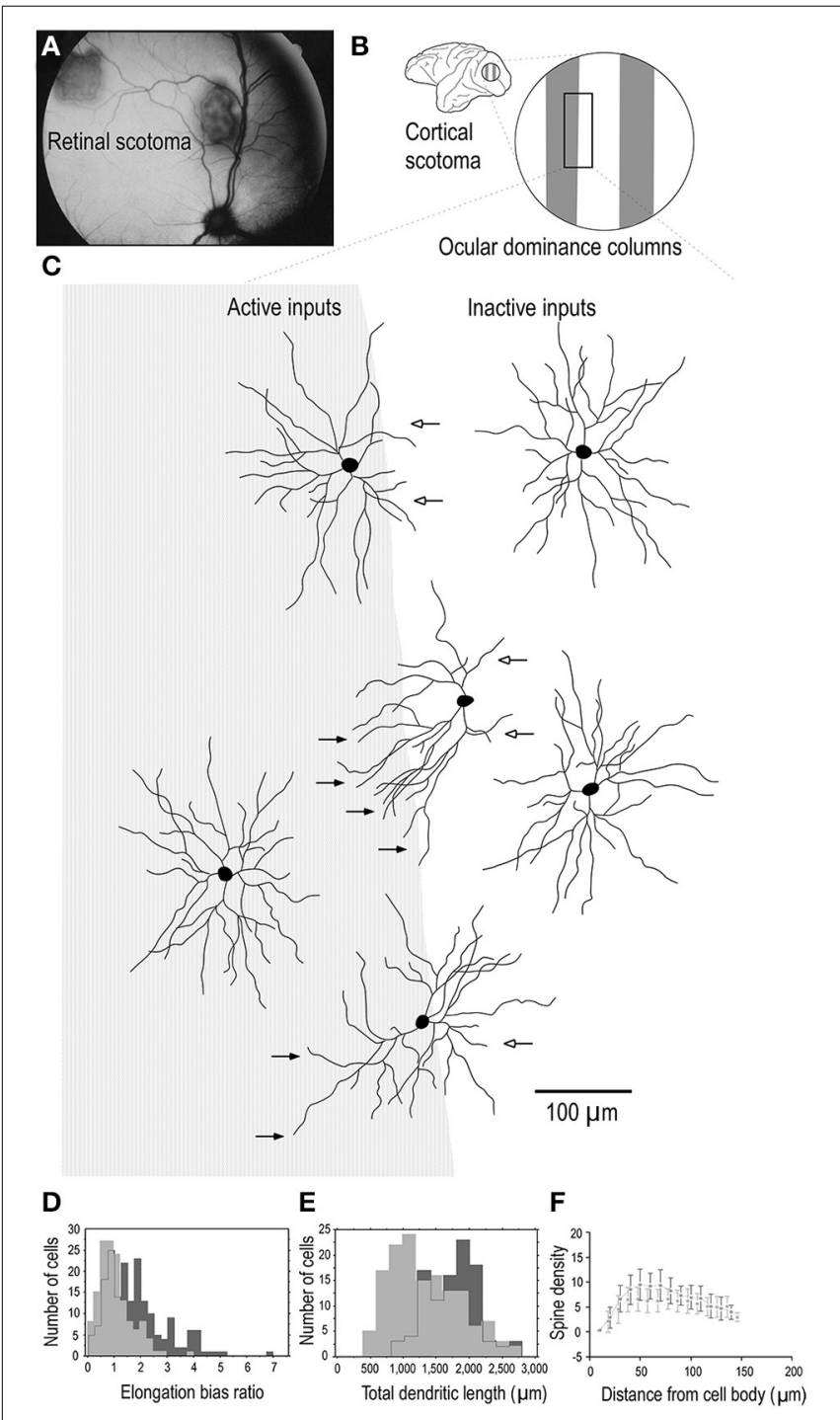

FIGURE 8 | Adult dendritic growth. Schematic illustrating placement of a retinal scotoma (laser lesion) $(\mathbf{A})$ in the adult macaque monkey, and the corresponding region of the contralateral $\mathrm{V} 1$ (B), in which individual neurons were injected across occular dominance columns (C). Cells located near a border of an ocular dominance column appeared to show a regression of dendrites which projected toward the center of the CO-poor column (open arrows) and an elongation of dendrites toward the CO-rich column (closed arrows). Cells located in the centers of the OD columns appeared to be relatively symmetrical. Comparison of over 400 layer III pyramidal cells intracellularly injected in 3 adult monkeys in which we placed monocular retinal lesions, and 5 age/gender/ hemisphere/layer-matched controls, revealed that the basal dendritic trees of layer III pyramidal neurons within the portion of $\mathrm{V} 1$ corresponding to the retinal lesion (the lesion projection zone, LPZ) undergo dendritic growth (D, E) and spinogenesis (F). Cells in the OD column corresponding to the non-lesioned eye within the LPZ have $65 \%$ more spines in their dendritic trees than those in the OD columns corresponding to the lesioned eye. The structural changes are not limited to cells within the LPZ in V1. Neurons in the region of cortex immediately surrounding the LPZ in V1 (the peri-LPZ) are considerably larger and more spinous than those within the LPZ. These cells have double the number of spines in their dendritic trees as compared with those in

age/gender/hemisphere/layer-matched controls. Others have also reported perturbations in the peri-LPZ in V1, including marked changes

(Continued) 


\section{FIGURE 8 | Continued}

in the expression of receptor subunits (Arckens et al., 2000) and expansion in receptive field sizes (Kaas et al., 1990; Chino et al., 1992; Schmid et al., 1996; Calford et al., 1999). In conjunction, these data suggest that anatomical and functional reorganization in the peri-LPZ differs in magnitude to that observed within the LPZ. Figure modified from Elston and DeFelipe (2002).

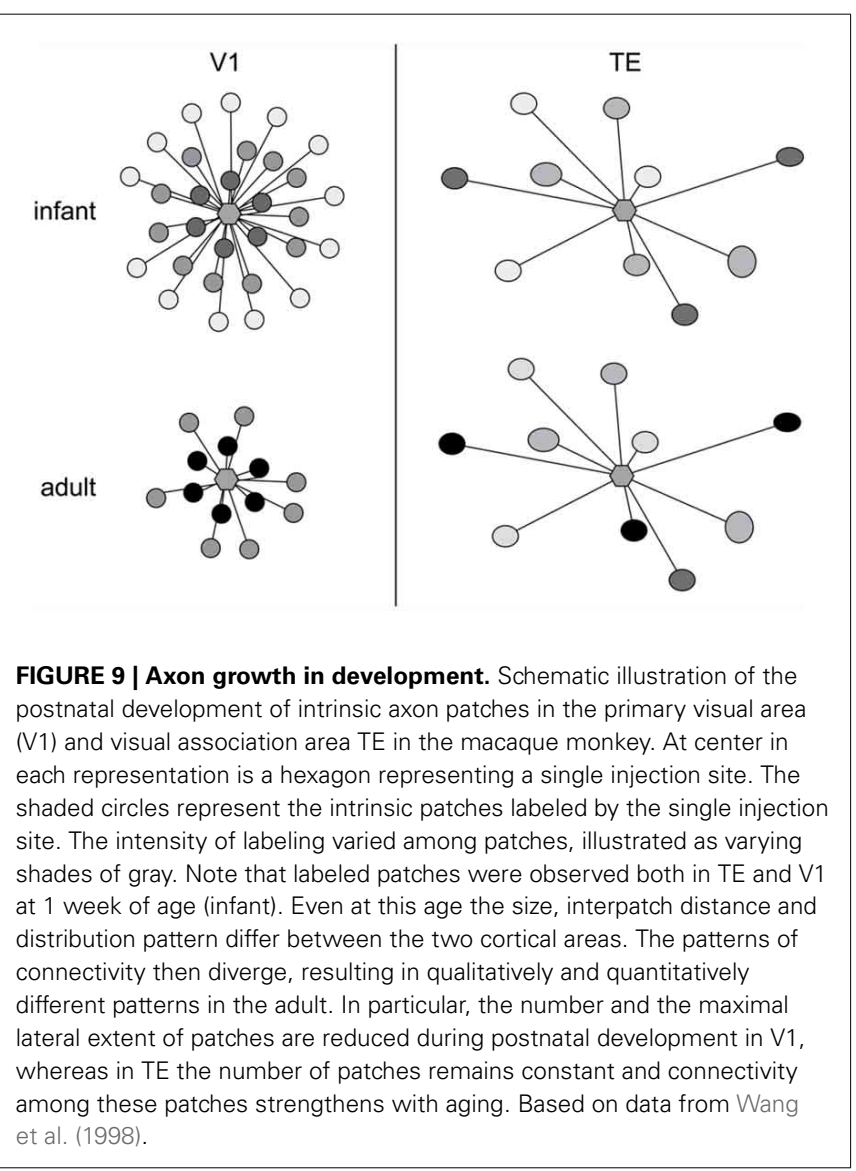

monkey: approximately $30-40$ spines per 10 micrometers (Oga et al., 2013; Sasaki et al., 2014).

In previous studies an estimate of the number of synapses per neuron were made at different ages by dividing the density of synapses in the neuropil with the number of neurons (Huttenlocher, 1979, 1990). These calculations made no distinction between asymmetrical and symmetrical synapses, nor between the different neuronal types (pyramidal vs. spiny stellate), nor compartmentalization within the dendritic trees (e.g., apical vs. basal dendrites). By studying the morphology of individual neurons, it is possible to calculate an estimate of the total number of excitatory synapses to that cell by quantifying the number of dendritic spines [i.e., each dendritic spine receives at least one excitatory input (DeFelipe et al., 1988; Petralia et al., 1994a,b,c; Arellano et al., 2007)]. By multiplying the spine density at a given increment along the dendrites with the number of branches at the corresponding distance it is possible to obtain a better estimate of the total number of excitatory synapses received by individual identified neurons.
These calculations revealed that different numbers of spines were grown in the dendritic trees of cells among these cortical areas, and then subsequently pruned. There was a net decrease in the number of spines in the dendritic trees of cells in V1, V2, V4, and A1 from birth to adulthood, whereas there was a net increase in the number of spines in the dendritic trees of cells in TEO, TE and prefrontal cortex area 12 during this same period (Elston et al., 2009, 2010a,b). In other words, pruning exceeds spinogenesis in V1, V2, V4, and A1 (early and middle sensory areas), whereas spinogenesis exceeds pruning in TEO, $\mathrm{TE}$ and prefrontal cortex (higher visual cortex and multimodal association cortex), during the normal course of postnatal development. It is worth noting that, on average, layer III pyramidal cells in prefrontal cortex grew 4 times the number of spines in their basal dendritic trees as did those in V1 (15,900 and 3900, respectively). The number of spines then pruned from cells in gPFC into adulthood (7400) equates to $>8$ times the total number of spines observed in the dendritic trees of pyramidal cells in V1 of the adult (600-900) (Elston et al., 2009). In the marmoset monkey, spinogenesis greatly exceeded pruning in areas TE and gPFC whereas in V1 spinogenesis slightly outweighed pruning in V1 (Oga et al., 2013).

One interpretation of these findings may be that all synaptic connections to the dendritic trees of pyramidal cells are formed by 3.5 months of age, some of which are then pruned into adulthood. However, such an interpretation can't account for the presence of dendritic spines throughout the entire dendritic trees of cells that continue to grow in size beyond 3.5 months of age. Nor can it account for the fact that where cells continue to increase in branching complexity beyond the peak in spinogenesis, spines are found studded along all dendrites. A more parsimonious interpretation is that although there may be net reduction in spine density in the dendritic trees of cells from 3.5 months of age into adulthood, new spines are continually grown through this period. What is revealed then in our data is a snapshot of the absolute number of dendritic spines accounting for new spine growth and spine loss. While such spinogenesis, dendrite growth and axogenesis has been demonstrated in the adult cortex following injury (Figure 8; e.g., Jones and Schallert, 1992; Darian-Smith and Gilbert, 1994; Jones et al., 1996; Elston and DeFelipe, 2002; Trachtenberg et al., 2002; Matsuzaki et al., 2004; Knott et al., 2006; Keck et al., 2008; Knott and Holtmaat, 2008; Sala et al., 2008), our data suggest adult spinogenesis is a feature of the normal healthy growing brain, that a percentage of spines are continually turned over, the average number per neuron varying among cortical areas. That is to say, dendrites and spines of pyramidal cells continue to grow throughout the entire life cycle, including infancy, childhood, adolescence, adulthood and senescence, as a normal process without the necessity of occasioning a trigger such as injury to the peripheral or central nervous system. At times there will be a net increase in neurite (dendrite, axon, spine) growth, at times there will be a net reduction in neurite growth.

\section{AXON PROJECTIONS}

The above data give us some insights into postnatal changes in the postsyanpatic matrix (dendritic spines and dendrites) in cortical circuitry, what then of the development of the presynaptic matrix 
(axons and axon boutons)? While it has been well documented that presynaptic matrix is characterized by a patchwork or latticelike structure in the adult cortex, and that the size and pattern of these patches vary among cortical areas (Rockland and Lund, 1982, 1983; Amir et al., 1993; Lund et al., 1993; Fujita and Fujita, 1996; Melchitzky et al., 1998, 2001; Tanigawa et al., 1998, 2005; González-Burgos et al., 2000), little is known of their development. Fujita and colleagues quantified the postnatal development of these axonal patches from birth to adulthood in areas V1 and TE of the macaque monkey (Wang et al., 1998). The axon patches are present at birth (PND7) and follow divergent maturation profiles with the onset of visual experience, with some shared characteristics. Of particular note was the decrease in the number of the patches is observed in V1 from PND7 to adulthood as compared with the trend in area TE where the number of patches remained consistent (Figure 9). There was also a decrease in the horizontal extent of the patches in V1 from PND7 to adulthood as compared with TE where the horizontal extent of axon patch labeling was maintained over the same period.

At the level of individual axons, in both V1 and TE axons within the patches were relatively straight at birth, and developed increasingly more varicosities with increasing postnatal age. In both $\mathrm{TE}$ and V1, the density of boutons along axons located within the patches increased with age, at least from infants. These data reveal that axonal branches and boutons within the patches in area TE continue to develop over many months, with connections being strengthened with aging. Previous studies revealed that the horizontal axons form this patchy pattern in $\mathrm{V} 1$ of the macaque monkey at least 3 weeks prior to birth (Coogan and Van Essen, 1996). Likewise, ipsilateral (Barone et al., 1996; Coogan and Van Essen, 1996) and callosal (Meissirel et al., 1991; Schwartz and Goldman-Rakic, 1991) corticocortical projections in macaque V1 are initially diffuse and then become patchy before birth. Although little is known of the patches in prenatal TE, and further studies are obviously needed, the maturity of horizontal axons at PND 7 (injection at PND 4) suggests that a patchy projection pattern is also established in utero in TE. Thus, patch formation does not likely require visual experience in either the striate cortex or extrastriate cortex, at least, in monkeys (see Schwartz and Goldman-Rakic, 1990, for a review).

\section{NEURONAL PHYSIOLOGY: DEVELOPMENTAL CHANGES AND AREAL SPECIALIZATION}

To test whether changes in the morphology of pyramidal cells during development outlined above influences cell physiology, Fujita and colleagues made intracellular whole-cell clamp recordings of pyramidal cells in V1 and TE from animals aged 10 days to 6 years of age (Maruyama et al., 2007). A number of physiological properties were quantified, including resting potential, firing threshold, membrane time constant, depolarizing sag, duration of individual action potentials, and spike-frequency adaptation. Most notably, membrane time constant, depolarizing sag, duration of individual action potentials, and spike-frequency adaptation ramped up until 7 months of age in cells in V1, but continued to ramp up over a protracted period of time in cells in TE. By contrast, the depolarizing sag increased through all ages in V1, but did not change until 1 year of age in TE. In addition to these changes in intrinsic membrane properties of individual neurons, synaptic transimission properites also change postnatally. For example, the excitatory postsynaptic currents recorded in layer III pyramidal cells at 15 months of age in the gPFC are considerably different to those recorded at 3 months of age (Gonzalez-Burgos et al., 2008) (Figure 10). These developmental differences in the electrophysiological signatures of pyramidal cells result in different, arguably specialized, functional signatures in the adult cortex. For example, Luebke and colleagues recently demonstrated in an elegant study that pyramidal cells in V1 have a significantly higher input resistance, depolarized resting membrane potential, higher action potential (AP) firing rates, lower spontaneous postsynaptic currents and faster kinetics

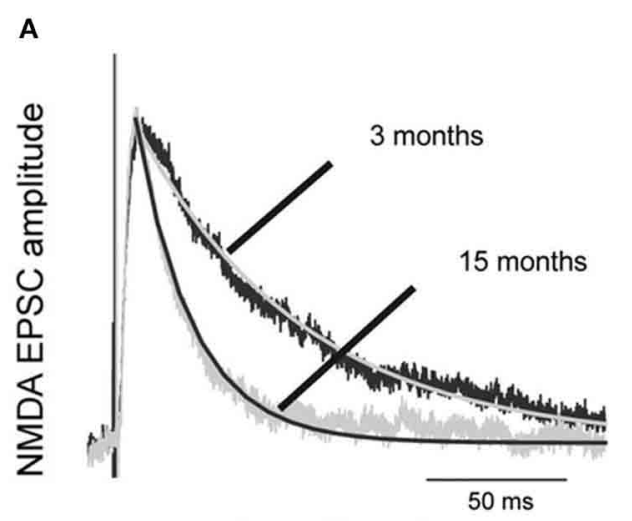

Time

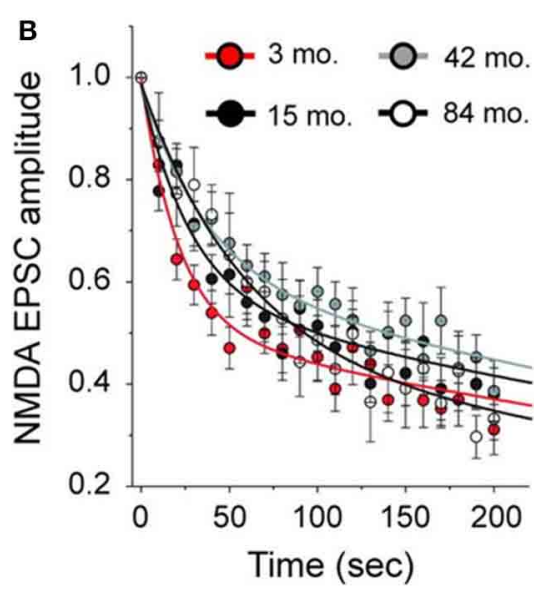

differences in duration. (B) The amplitude of NMDA-EPSCs was normalized relative to that of the first response recorded after resuming stimulation in the presence of an NMDA antagonist, MK801. The lines represent double-exponential functions fit to the data from animals of different ages by non-linear regression. Modified from Gonzalez-Burgos et al. (2008). 
than those in granular PFC (Amatrudo et al., 2012) (Figure 11). Moreover, pyramidal cells in V1 and TE of the mature brain show a diametrically opposed reaction to extrinsic tetanic stimulation: extracellular stimulation $(20-40$ pulses at $40-100 \mathrm{~Hz}$, applied every $4 \mathrm{~s}$ for $3-5 \mathrm{~min}$ ) of intrinsic horizontal connections of layers 2 and 3 results in long term depression (LTD) of extracellular potentials in V1 and long term potentiation (LTP) in TE (Murayama et al., 1997). Although Luebke and colleagues were unable to demonstrate such changes in the electrophysiological properties in V1 by in vitro recording (Luebke et al., 2013), on balance, we suggest the above data reveal that the anatomical and electrophysiological profiles of pyramidal cells vary among cortical areas at birth, and continue to diverge into adulthood.
Comparison of the results of studies in primates with those in rodents reveals some interesting differences in their electrophysiological properties with aging. For example, whereas resting potential of layer III pyramidal cells remained unchanged in V1 and TE of the macaque monkey, there is a significant change in these same cells in A1 of the mouse (Oswald and Reyes, 2008; Romand et al., 2011). Input resistance of layer III pyramidal cell differed between $\mathrm{V} 1$ and TE of the macaque monkey remained unchanged with age. In mouse $\mathrm{A} 1$, the input resistance of layer III pyramidal cells decreased with aging (Metherate and Aramakis, 1999; Oswald and Reyes, 2008). Neuronal discharge following an intracellularly applied electrical pulse increased with age in layer III pyramidal cells in mouse A1, as was the case in macaque V1, but decreased in macaque TE. Discharge with

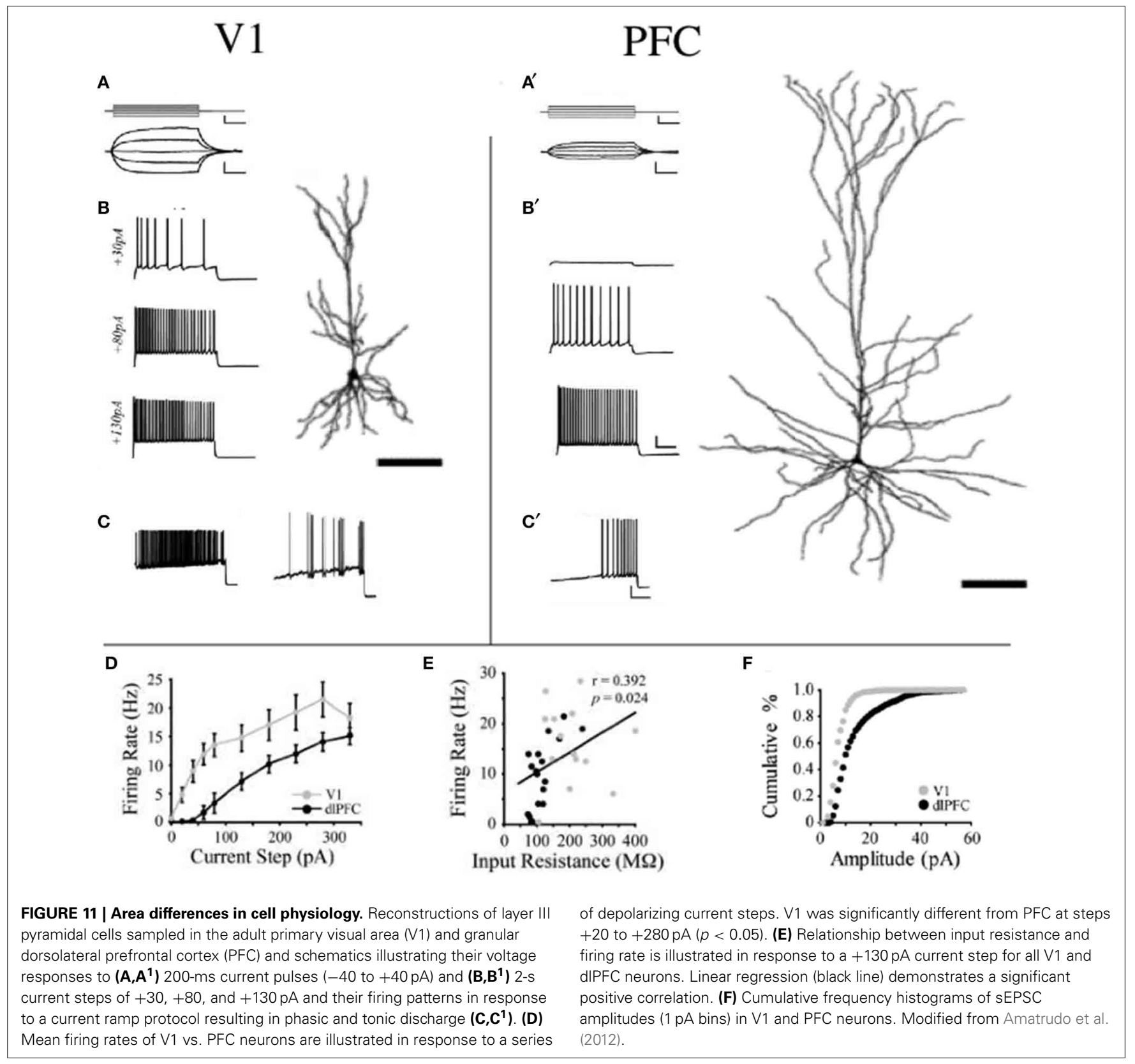


increasing age also increased in layer $\mathrm{V}$ pyramidal cells in rat prelimbic cortex (Zhang, 2004). Zhang (2004) also reported a decrease in input resistance, resting potential and time constant with aging, as also reported in layer V pyramidal cells in rat visual and somatosensory cortex (McCormick and Prince, 1987; Kasper et al., 1994). Clearly then, the electrophysiological properties of pyramidal cells may vary independently among different cortical layers, different cortical areas and different species.

It is worth remembering that while pyramidal cells vary in size and branching complexity among cortical areas in some rodents (Benavides-Piccione et al., 2002, 2006; Ballesteros-Yáñez et al., 2006; Elston et al., 2006b), the extent of this variation is but a small fraction of that reported in higher primates. For example, in the mouse there is a 2-fold difference in the number of dendritic spines in the basal dendritic trees of layer III pyramidal cells across the adult cortical mantle. In adult primates, there is a 23 -fold difference in the number of dendritic spines in the basal dendritic trees of layer III pyramidal cells between V1 and the gPFC (see Elston, 2003a, for a review). Accordingly, differences in the postnatal developmental profiles of pyramidal cell electrophysiology reported in rodents may well to underscore that evident in primates.

\section{NEURONAL RECEPTIVE FIELD PROPERTIES IN POSTNATAL DEVELOPMENT}

Movshon et al. (1999, 2000) demonstrated that receptive field sizes of neurons located in the central 5 degrees of the visual representation in V1 decrease in size from early postnatal development to adulthood. In addition, they demonstrated that the spatial resolution of cells in V1 (the highest spatial frequency at which cells give a response of at least $10 \%$ of its maximum) increases from birth to adulthood. There is also a general trend for increasing surround suppression from birth to adulthood (Kiorpes and Movshon, 2003; Chino et al., 2004) and facilitation develops slowly over the first year after birth (Li et al., 2013). These changes in receptive field size, spatial acuity and surround suppression could plausibly be attributed to changes in the geometrical sampling of neurons as their dendritic trees change shape (Sholl, 1955; Ferster, 1998; Taylor et al., 2000; Taylor and Vaney, 2002). Specifically, as the dendritic trees of neurons decrease in size with maturation they may sample a progressively smaller portion of the visuotopically organized afferent projection and thus have progressively smaller receptive fields. The developmental time course of sensivity to global form and motion and visual texture modulation have been shown to be measured in years, rather than months (Kiorpes and Movshon, 2004; ElShamayleh et al., 2010; Kiorpes et al., 2012). In conjunction these data suggested a protracted developmental profile for neurons in V1, both morphologically and functionally, that extends well beyond the peak synaptogeneses demonstrated relatively early in development (Figure 12).

Chino and colleagues (Zhang et al., 2008) reported that in V2, receptive fields of neurons mature later than those in V1 neurons, consistent with our finding that the dendritic trees of pyramidal cells in V2 continue to grow from 2D to $3 \frac{1}{2}$ months of age while those in V1 become smaller during this time. Although they report that by 4 weeks of age the spatial receptive field structure in V2 is as complex as in adults (Zhang et al., 2013), but their ability to discriminate fine disparity differences was significantly reduced compared with adults (Maruko et al., 2008). V2 neurons of 8-week-old monkeys had significantly lower optimal temporal frequencies and resolutions than those of adults (Zheng et al., 2007). Neurons in area TE do not develop their adult-like response properties until even later in development (Rodman et al., 1993), consistent with our findings of continued growth and branching from birth. Furthermore, anatomical connections of TE undergo a protracted period of refinement from birth to adulthood compared to other visual areas (Webster et al.,
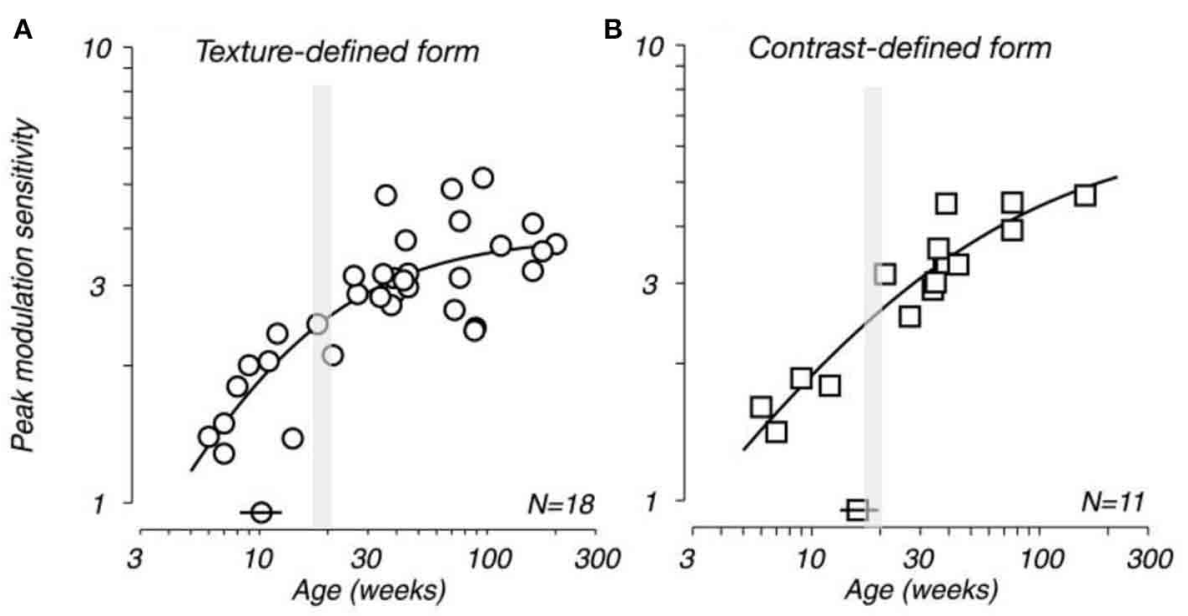

FIGURE 12 | Developing visual sensitivity. Plots illustrating the developmental time course of peak behavioral modulation sensitivity for (A) texture-defined and (B) contrast-defined form as a function of age. Isolated symbols intersected by horizontal bars (above the $x$-axis) indicate the age at which modulation sensitivity reached half of adult levels (10 and 17 weeks for
A,B, respectively). N indicates the number of monkeys tested. Because many of these subjects were tested longitudinally, each plot contains more data points than the indicated population size. Note that the peak spine and synapse density occurs at approximately 3.5 months of age (gray shading). Modified from El-Shamayleh et al. (2010). 


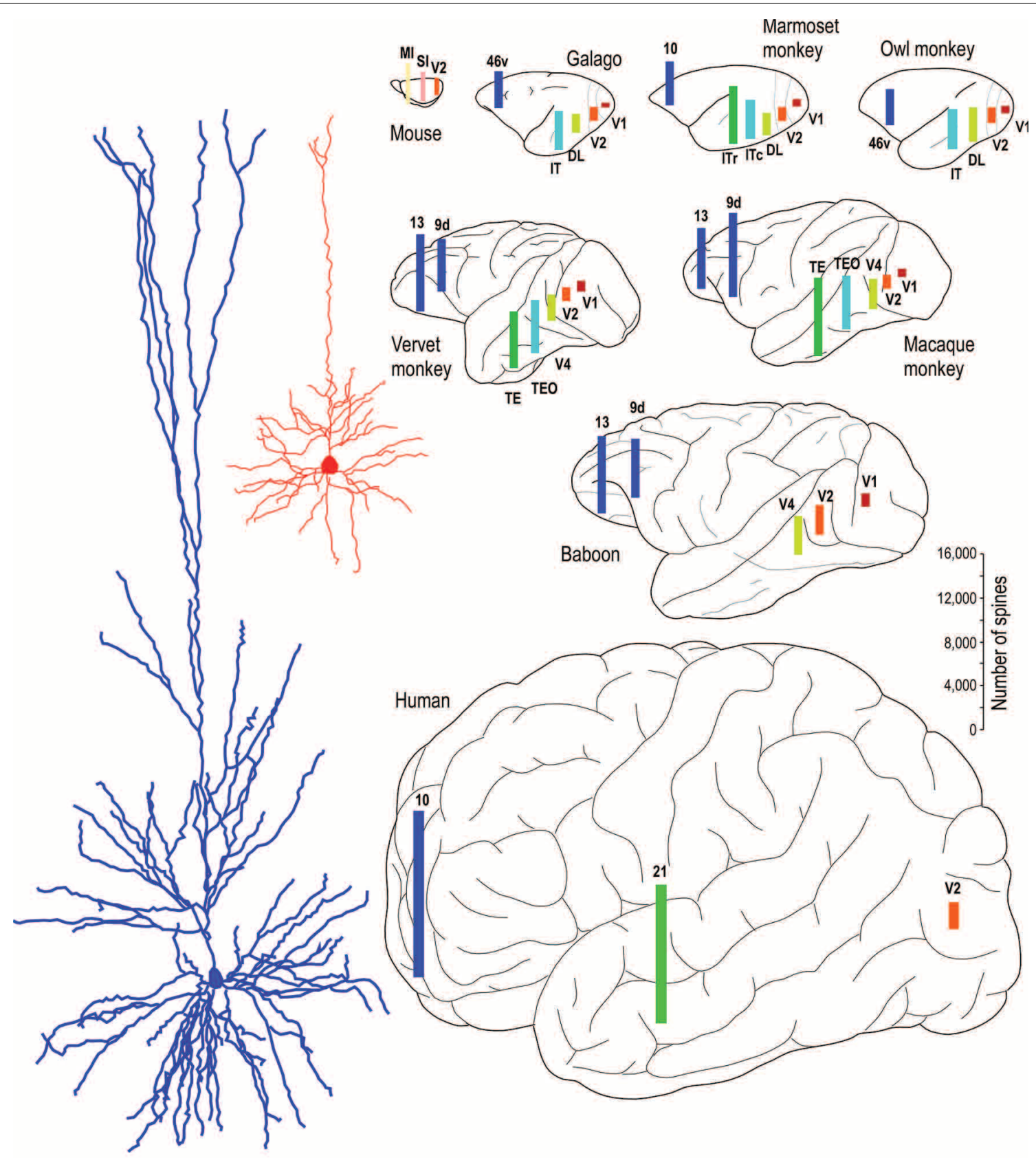

FIGURE 13 | Specialization in pyramidal cell structure in the adult brain. Schematic illustrating regional and species differences in pyramidal cell structure. At left are illustrated two individual layer III cells sampled from the primary visual area (V1) and the inferotemporal cortical area TEpd of the adult macaque monkey. Note the difference in thickness of layer III between the two cortical areas, the tangential extent of both the basal and apical dendritic trees. Illustrated at right are the estimates of the total number of spines in the basal dendritic trees of layer III pyramidal cells in visual areas V1, V2, V4 (DL), TEO (ITC), TE (ITr), and prefrontal cortex (areas 9d, 10, 13, and 46v of Preuss and

Goldman-Rakic, 1991). Prefrontal cortex refers as originally defined by Brodmann (1913) as granular cortex anterior to the central sulcus (see Elston and Garey, 2004, for a translation). Bars are color coded for homology, that is, homologous/analagous cortical areas are illustrated by a single color. The bars representing the number of spines are not necessarily located in the exact position from which the cells were sampled, but have been positioned for aesthetic balance. Schematics of the different brains are not drawn to scale. Data taken from the mouse (Ballesteros-Yáñez et al., 2006), galago (Elston et al., 2005b,c), owl monkey (Elston, 2003b,c), marmoset monkey (Elston et al., 1999b, 2001), vervet monkey (Elston et al., 2005d, 2011b), macaque monkey (Elston and Rosa, 1997, 1998; Elston et al., 1999a, 2001, 2011b; Elston, 2000), baboon (Elston et al., 2005e, 2011 b) and human (Elston et al., 2001). Systematic differences have also been demonstrated in the total number of spines in the basal dendritic trees of layer III pyramidal cells in sensorimotor and cingunalte cortex in all species studied to date, including the adult vervet monkey, macaque monkey and baboon (Elston and Rockland, 2002; Elston et al., 2005a,f,g,h,i) (not illustrated). 
1991, 1994, 1995; Rodman and Consuelos, 1994; Barone et al., 1996; Coogan and Van Essen, 1996) and this region becomes myelinated much later in development than V1 (Rodman, 1994). The anatomical data in TEO and TE, which reveal progressively larger dendritic trees from birth to adulthood, parallel the physiological data for increasing receptive field size during postnatal maturation.

In addition to the size of the dendritic trees, their branching structure may influence aspects of cellular function. Considerable work has been done in the retina relating neuronal branching structure to functional qualities such as direction selectivity (see Vaney et al., 2012, for a review). Although less well studied, it has been proposed that dendrtic branching structure may be important in V1, for example, in determining orientation and direction selectivity (Pettigrew, 1974; Tieman and Hirsch, 1982; Elston and Rosa, 1997; Ferster, 1998; Livingstone, 1998). Moreover, the onset of form discrimination at 3 weeks of age (Zimmermann, 1961) occurs at the time when cells are most branched. Could the increase in the number of branches facilitate compartmentalization of processing within the dendritic tree (Poirazi and Mel, 2001; Chklovskii et al., 2004) and allow detection of inputs associated with asymmetric features throughout the dendritic tree?

\section{SPECIALIZED PYRAMIDAL CELL GROWTH PROFILES RESULT IN SPECIALIZED CORTICAL CIRCUITS IN THE MATURE BRAIN}

Whatever the explanation, the different developmental profiles result in marked differences in pyramidal cell structure among cortical areas in the mature brain (Figure 13). Cells become increasingly larger and more spinous with anterior progression through visual areas V1, V2, V4, TEO, and TE (Elston and Rosa, 1997, 1998; Elston et al., 1999b, 2005b,d,e; Elston, 2003b). Likewise, cells become increasingly larger and more spinous with progression through somatosensory areas 3b, 5, and 7 (Elston and Rockland, 2002; Elston et al., 2005h,i). Those in polysensory cortex, such as the superior temporal polysensory area (STP) are larger and more spinous than those in TE (Elston et al., 1999a). Those in cingulate cortex are larger and more spinous than those in sensory and sensory association cortex (Elston et al., 2005a,f,g), and those in prefrontal cortex are among the most spinous of all pyramidal cells in the cerebral cortex (Elston et al., 2001, 2011b; Jacobs et al., 2001; Bianchi et al., 2012). It has also been demonstrated that pyramidal cells are increasingly more complex in structure and more spinous in primate species with increasingly larger granular prefrontal cortex (Elston et al., 2005c, 2006a, 2011b). Pyramidal cells in the adult brain of rodents and primates appear also to be influenced by different developmental and phylogenetic controls (Elston and Manger, 2014). Pyramidal cells in V1 of adult rodents vary considerably among species, being larger, more branched and more spinous with increasing size of $\mathrm{V} 1$, whereas that in adult primate V1 is relatively constant, irrespective of the size of V1 (Figure 14).

These structural differences potentially influence the number of inputs received by pyramidal cells in any given cortical area, the manner in which these inputs are integrated within the dendritic trees, and the degree of interconnectivity between neurons
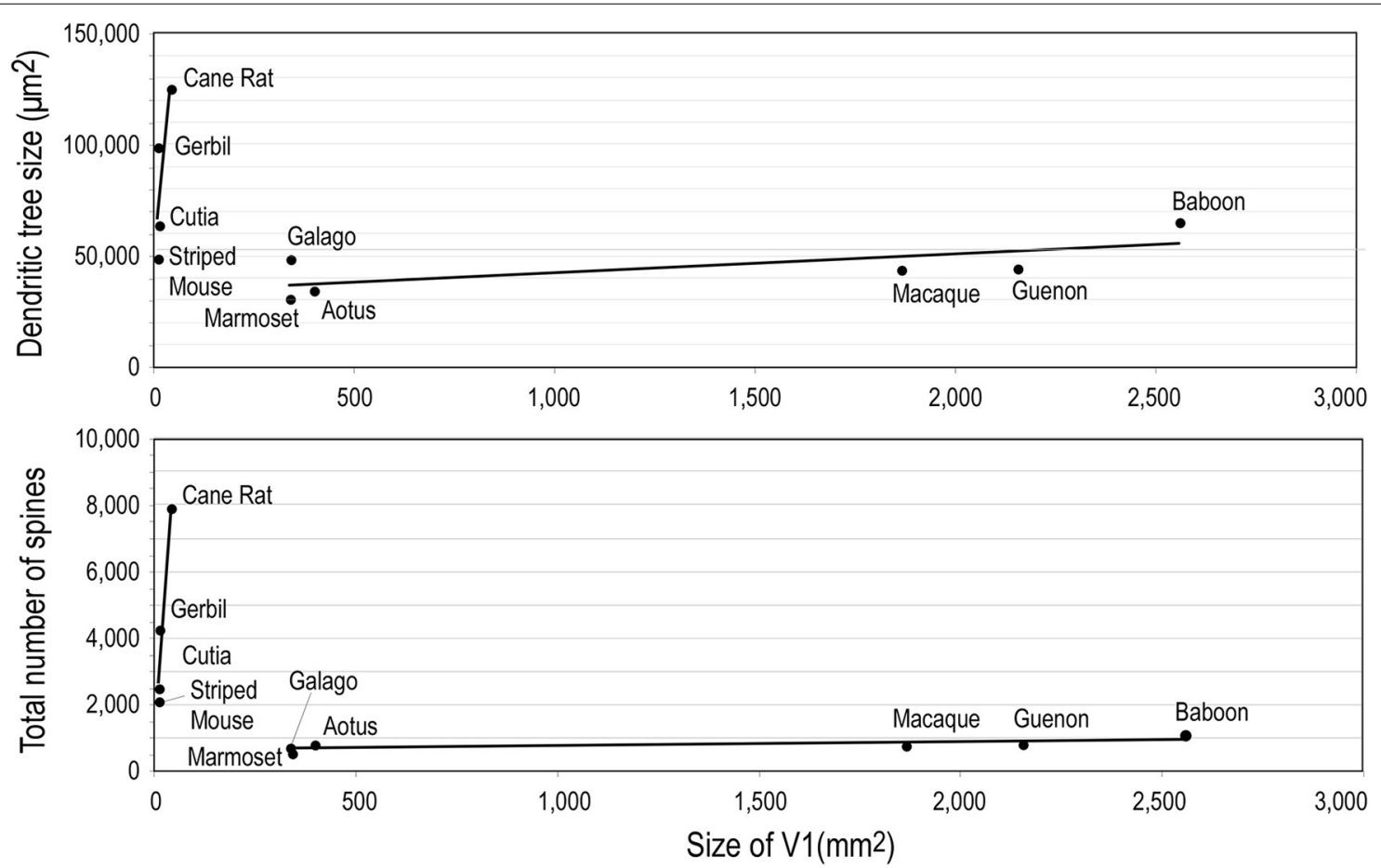

FIGURE 14 | Neuron growth and cortical size. Graphs illustrating phylogentic differences in the trends between pyramidal cell structure and size of the of the primary visual area (V1) in rodents and primates. Illustrated are the size of, and number of dendritic spines in, the "average" pyramidal cell vs. the size V1 in the cane rat, bushvelt gerbil, striped mouse, agouti (cutia), tree shrew, galago, marmoset monkey, owl monkey, guenon (vervet monkey), macaque monkey, and baboon. Separate trend lines (linear regressions) are illustrated for the rodent and primate data (reproduced from Elston and Manger, 2014). 
within cortical circuits (Jacobs and Scheibel, 2002; Elston, 2003a, 2007; London and Häusser, 2005; Spruston, 2008). In V1, the differences in the size of the dendritic trees, in the tangential plane, influence the portion of the visutopic representation sampled by individual cells (Figure 15). Both the functional capacity of neurons and their potential for plastic change have been correlated with their morphological complexity (Poirazi and Mel, 2001; Chklovskii et al., 2004). Moreover, the different structural complexity of pyramidal cells in sensory, association and executive cortex may provide an anatomical platform for tonic vs. phasic sampling, believed to be important for memory (Miller and Cohen, 2001; Funahashi and Takeda, 2002; Elston, 2007).

In addition, differences have also been reported in inhibitory circuitry among cortical areas in the adult brain. Specifically, the density and connectivity of interneurons may differ among cortical areas (Hof and Nimchinsky, 1992; Kritzer et al., 1992; Kondo et al., 1994; Hof and Morrison, 1995; DeFelipe et al., 1999; Elston and González-Albo, 2003; Yáñez et al., 2005; Benavides-Piccione and DeFelipe, 2007; Freire et al., 2010, 2012). The different types of interneurons, such as Chandelier cells, Martinotti cells and basket cells, project to different compartments of pyramidal cells, including the soma, axon initial segment and dendrites (see DeFelipe, 1993; Somogyi et al., 1998; DeFelipe et al., 2002 for reviews). The differences in both the density and distribution of interneurons, and pyramidal cell structure, among cortical areas result in quantifiably different patterns of connectivity (DeFelipe et al., 1999; Elston et al., 1999d; Blazquez-Llorca et al., 2010; da Rocha et al., 2012). In future studies it will be of particular interest to determine the developmental profiles of inhibitory neurons (e.g., Anderson et al., 1995), especially in view of the different types of neuronal migration during development: radial and tangential (see Rakic, 1990; Nakajima, 2007; Jones, 2009; Chédotal, 2010; Govek et al., 2011 for reviews). It will also be of great importance to expand the scope of research to identify possible species differences in postnatal development of cortical circuitry, particularly in human prefrontal cortex which is disproportionately large compared with that in other primates (Brodmann, 1913) translated by Elston and Garey (2004), to better comprehend the development of the neural substrate for cognitive functions (see Fuster, 1997; Goldman-Rakic, 1999; Preuss, 2000; Elston, 2007; Rakic, 2009 for reviews).

\section{CONCLUSIONS}

Recent cell injection studies reveal variation in the developmental profiles of pyramidal cells among different cortical areas in the primate brain. The different growth profiles of pyramidal cells among cortical areas potentially influence the number of inputs received by neurons in any given cortical area, the manner in which these inputs are integrated within the dendritic trees, and the degree of connectivity between neurons. Together, these features may influence the physiological properties of the cells, and the circuitry they compose. Moreover, the data reveal that spine loss in the developing cortex does not result solely from the pruning of existing spines observed at the peak (approximately 3 months of age) but, rather, by the net reduction of existing and newly acquired spines (both those formed by 3 months of age and in the more mature cortex). Furthermore, the rate of spine loss in

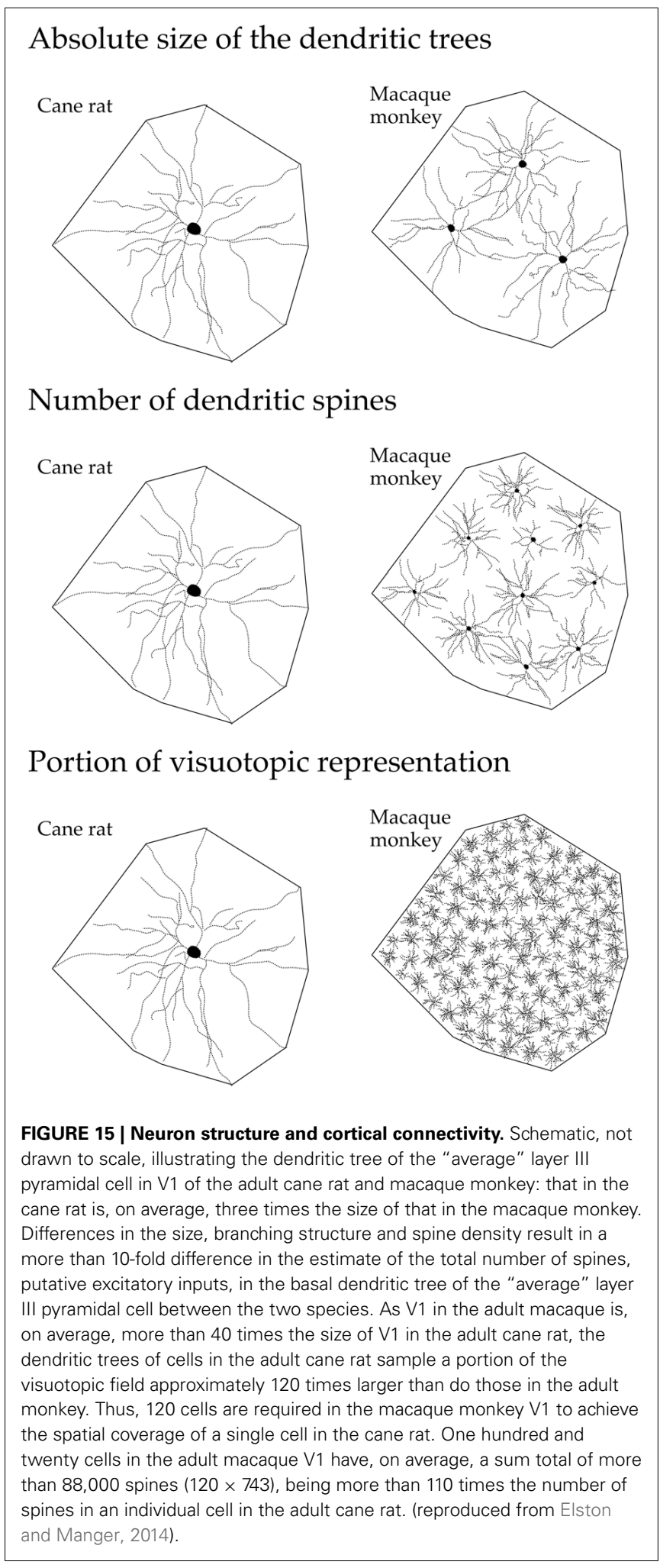

the dendritic trees of pyramidal cells varies among cortical areas in both absolute and relative terms. The "use it or lose it" principle may belie the diversity of mechanisms that drive synapse stabilization or elimination in the developing and mature cerebral cortex. 
Use it but you may still lose it may prove to be just as, if not more, prevalent in the developing brain.

\section{FUNDING}

This work was supported by an RD Wright Fellowship from the National Health and Medical Research Council of Australia (210341: GNE) and grants from the Japan Science and Technology Agency (Core Research for Evolutional Science and Technology), the Ministry of Education, Science, Sports, and Culture (Japan; grant number 17022025), Osaka University, and the I Hear Innovation Foundation (Australia) and the Sunshine Coast Regional Council (Australia).

\section{ACKNOWLEDGMENT}

We thank Tomofumi Oga and Hirosato Aoi for assistance with preparing some of the figures.

\section{REFERENCES}

Amatrudo, J. M., Weaver, C. M., Crimins, J. L., Hof, P. R., Rosene, D. L., and Luebke, J. I. (2012). Influence of highly distinctive structural properties on the excitability of pyramidal neurons in monkey visual and prefrontal cortices. J. Neurosci. 32, 13644-13660. doi: 10.1523/JNEUROSCI.2581-12.2012

Amir, Y., Harel, M., and Malach, R. (1993). Cortical hierarchy reflected in the organization of intrinsic connections in macaque monkey visual cortex. J. Comp. Neurol. 334, 19-46. doi: 10.1002/cne.903340103

Anderson, S. A., Classey, J. D., Condé, F., Lund, J. S., and Lewis, D. A. (1995). Synchronous development of pyramidal neuron dendritic spines and parvalbumin immunoreactive chandelier neuron axon terminals in layer III of monkey prefrontal cortex. Neuroscience 67, 7-22. doi: 10.1016/0306-4522(95)00051-J

Arckens, L., van der Gucht, E., Eysel, T. H., Orban, G., and Vandesande, F. (2000). Investigation of cortical reorganization in area 17 and nine extrastriate visual areas through the detection of changes in immediate early gene expression as induced by retinal lesions. J. Comp. Neurol. 425, 531-544. doi: 10.1002/10969861(20001002)425:4\%3C531::AID-CNE5\%3E3.0.CO;2-J

Arellano, J. I., Espinosa, A., Fairén, A., Yuste, R., and DeFelipe, J. (2007). Non-synaptic dendritic spines in neocortex. Neuroscience 145, 464-469. doi: 10.1016/j.neuroscience.2006.12.015

Ballesteros-Yáñez, I., Benavides-Piccione, R., Elston, G. N., Yuste, R., and DeFelipe, J. (2006). Density and morphology of pyramidal cell dendritic spines in the mouse neocortex. Neuroscience 138, 403-409. doi: 10.1016/j.neuroscience.2005.11.038

Barone, P., Dehay, C., Berland, M., and Kennedy, H. (1996). Role of directed growth and target selection in the formation of cortical pathways: prenatal development of the projection of area V2 to V4 in the monkey. J. Comp. Neurol. 374, 1-20.

Becker, L. E., Armstrong, D. L., Chan, F., and Wood, M. M. (1984). Dendritic development in human occipital cortical networks. Devel Brain Res. 13, 117-124. doi: 10.1016/0165-3806(84)90083-X

Benavides-Piccione, R., Ballesteros-Yáñez, I., DeFelipe, J., and Yuste, R. (2002). Cortical area and species differences in dendritic spine morphology. J. Neurocytol. 31, 337-346. doi: 10.1023/A:1024134312173

Benavides-Piccione, R., and DeFelipe, J. (2007). Distribution of neurons expressing tyrosine hydroxylase in the human cerebral cortex. J. Anat. 211, 212-222. doi: 10.1111/j.1469-7580.2007.00760.x

Benavides-Piccione, R., Hamzei-Sichani, F., Ballesteros-Yáñez, I., DeFelipe DeFelipe, J., and Yuste, R. (2006). Dendritic size of pyramidal neurons differs among mouse cortical regions. Cereb. Cortex 16, 990-1001. doi: 10.1093/cercor/bhj041

Bianchi, S., Stimpson, C. D., Bauernfeind, A. L., Schapiro, S. J., Baze, W. B., McArthur, M. J., et al. (2012). Dendritic morphology of pyramidal neurons in the chimpanzee neocortex: regional specializations and comparison to humans. Cereb. Cortex 23: 2429-2436. doi: 10.1093/cercor/bhs239

Bianchi, S., Stimpson, C. D., Duka, T., Larsen, M. D., Janssen, W. G. M., Collins, Z., et al. (2013). Synaptogenesis and development of pyramidal neuron dendritic morphology in the chimpanzee neocortex resembles humans. Proc. Natl. Acad. Sci. U.S.A. 110(Suppl. 2), 10395-10401. doi: 10.1073/pnas.1301224110
Blazquez-Llorca, L., García-Marín, V., and DeFelipe, J. (2010). GABAergic complex basket formations in the human neocortex. J. Comp. Neurol. 518, 4917-4937. doi: 10.1002/cne.22496

Boothe, R. G., Greenough, W. T., Lund, J. S., and Wrege, K. (1979). A quantitative investigation of spine and dendrite development of neurons in visual cortex (area 17) of Macaca nemistrina monkeys. J. Comp. Neurol. 186, 473-490. doi: $10.1002 / \mathrm{cne} .901860310$

Bourgeois, J.-P., Jastreboff, P. J., and Rakic, P. (1989). Synaptogenesis in visual cortex of normal and preterm monkeys: evidence for intrinsic regulation of synaptic overproduction. Proc. Natl. Acad. Sci. U.S.A. 86, 4297-4301. doi: 10.1073/pnas.86.11.4297

Bourgeois, J.-P., and Rakic, P. (1993). Changes of synaptic density in the primary visual cortex of the macaque monkey from fetal to adult stage. J. Neurosci. 13, 2801-2820.

Brodmann, K. (1909). Vergleichende Lokalisationslehre der Großhirnrinde. Leipzig: Johann Ambrosius Barth.

Brodmann, K. (1913). Neue Forschungsergebnisse der Grosshirnrindenanatomie mit besonderer Berücksichtigung anthropologischer Fragen. Geselsch Deuts Naturf Artze 85, 200-240.

Calford, M. B., Schmid, L. M., and Rosa, M. G. P. (1999). Monocular focal retinal lesions induce short-term topographic plasticity in adult cat visual cortex. Proc. R. Soc. B Biol. Ser. 266, 499-507.

Chédotal, A. (2010). Should I stay or should I go? Becoming a granule cell. Trends Neurosci. 33, 163-172. doi: 10.1016/j.tins.2010.01.004

Chino, Y. M., Bi, M., and Zhang, B. (2004). "Normal and abnormal development of the neuronal response properties in primate visual cortex," in The Primate Visual System, eds J. H. Kaas and C. Collins (Boca Raton, FL: CRC Press), 81-108.

Chino, Y. M., Kaas, J. H., Smith, E. L. III., Langston, A. L., and Cheng, H. (1992). Rapid reorganization of cortical maps in adult cats following restricted deafferentation in retina. Vision Res. 32, 789-796. doi: 10.1016/00426989(92)90021-A

Chklovskii, D. B., Mel, B. W., and Svoboda, K. (2004). Cortical rewiring and information storage. Nature 431, 782-788. doi: 10.1038/nature03012

Conel, J. L. (1941). "The cortex of a one month old infant," in The Post Natal Development of the Human Cerebral Cortex (Cambridge: Harvard University Press). doi: 10.4159/harvard.9780674187658

Conel, J. L. (1947). "The cortex of a three month old infant," in The Post Natal Development of the Human Cerebral Cortex (Cambridge: Harvard University Press). doi: 10.4159/harvard.9780674187672

Conel, J. L. (1955). "The cortex of a fifteen month old infant," in The Post Natal Development of the Human Cerebral Cortex (Cambridge: Harvard University Press). doi: 10.4159/harvard.9780674187696

Conel, J. L. (1959). "The cortex of a twenty-four month old infant," in The Post Natal Development of the Human Cerebral Cortex (Cambridge: Harvard University Press). doi: 10.4159/harvard.9780674187702

Conel, J. L. (1963). "The cortex of a four year old child," in The Post Natal Development of the Human Cerebral Cortex (Cambridge: Harvard University Press). doi: 10.4159/harvard.9780674187719

Conel, J. L. (1967). "The cortex of a six year old child," in The Post Natal Development of the Human Cerebral Cortex (Cambridge: Harvard University Press). doi: 10.4159/harvard.9780674187733

Coogan, T. A., and Van Essen, D. C. (1996). Development of connections within and between areas V1 and V2 of macaque monkeys. J. Comp. Neurol. 372, 327-342.

Cupp, C. J., and Uemura, E. (1980). Age-related changes in the prefrontal cortex of Macaca mulatta: quantitative analysis of dendritic branching patterns. Exp. Neurol. 69, 143-163. doi: 10.1016/0014-4886(80)90150-8

Darian-Smith, C., and Gilbert, C. D. (1994). Axonal sprouting accompanies functional reorganization in adult striate cortex. Nature 368, 737-740. doi: $10.1038 / 368737 \mathrm{a} 0$

da Rocha, E. G., Freire, M. A. M., Bahia, C. P., Pereira, A., Sosthenes, M. C. K., Silveira, L. C. L., et al. (2012). Dendritic structure varies as a function of eccentricity in V1: a quantitative study of NADPH diaphorase neurons in the diurnal South American rodent agouti, Dasyprocta prymnolopha. Neuroscience 216, 94-102. doi: 10.1016/j.neuroscience.2012. 04.042

DeFelipe, J. (1993). Neocortical neuronal diversity: chemical heterogeneity revealed by colocalization studies of classic neurotransmitters, neuropeptides, 
calcium-binding proteins, and cell surface molecules. Cereb. Cortex 3, 273-289. doi: $10.1093 /$ cercor/3.4.273

DeFelipe, J., Alonso-Nanclares, L., and Arellano, J. I. (2002). Microstructure of the neocortex: comparative aspects. J. Neurocytol. 31, 299-316. doi: 10.1023/A:1024130211265

DeFelipe, J., Conti, F., Van Eyck, S. L., and Manzoni, T. (1988). Demonstration of glutamate-positive axon terminals forming asymmetric synapses in cat neocortex. Brain Res. 455, 162-165. doi: 10.1016/0006-8993(88)90127-8

DeFelipe, J., del Río, M. R., González-Albo, M. C., and Elston, G. N. (1999). Distribution and patterns of connectivity of interneurons containing calbindin, calretinin and parvalbumin in visual areas of the occipital and temporal lobes of the macaque monkey. J. Comp. Neurol. 412, 515-526.

Eayrs, J. T., and Goodhead, B. (1959). Postnatal development of the cerebral cortex in the rat. J. Anat. 93, 385-402.

El-Shamayleh, Y., Movshon, J. A., and Kiorpes, L. (2010). Development of sensitivity to visual texture modulation in macaque monkeys. J. Vis. 10, 11. doi: $10.1167 / 10.11 .11$

Elston, G. N. (2000). Pyramidal cells of the frontal lobe: all the more spinous to think with. J. Neurosci. 20, RC95.

Elston, G. N. (2001). Interlaminar differences in the pyramidal cell phenotype in areas $7 \mathrm{~m}$ and STP (the superior temporal polysensory area) of the macaque monkey. Exp. Brain Res. 138, 141-152. doi: 10.1007/s002210100705

Elston, G. N. (2003a). Cortex, cognition and the cell: new insights into the pyramidal neuron and prefrontal function. Cereb. Cortex 13, 1124-1138. doi: 10.1093/cercor/bhg093

Elston, G. N. (2003b). Pyramidal cell heterogeneity in the visual cortex of the nocturnal New World owl monkey (Aotus trivirgatus). Neuroscience 117, 213-219. doi: 10.1016/S0306-4522(02)00806-0

Elston, G. N. (2003c). The pyramidal neuron in occipital, temporal and prefrontal cortex of the owl monkey (Aotus trivirgatus): regional specialization in cell structure. Eur. J. Neurosci. 17, 1313-1318. doi: 10.1046/j.14609568.2003.02552.x

Elston, G. N. (2007). "Specializations in pyramidal cell structure during primate evolution," in Evolution of Nervous Systems, eds J. H. Kaas and T. M. Preuss (Oxford: Academic Press), 191-242.

Elston, G. N., Benavides-Piccione, R., and DeFelipe, J. (2001). The pyramidal cell in cognition: a comparative study in human and monkey. J. Neurosci. 21, RC163.

Elston, G. N., Benavides-Piccione, R., and DeFelipe, J. (2005a). A study of pyramidal cell structure in the cingulate cortex of the macaque monkey with comparative notes on inferotemporal and primary visual cortex. Cereb. Cortex 15, 64-73. doi: 10.1093/cercor/bhh109

Elston, G. N., Benavides-Piccione, R., Elston, A., DeFelipe, J., and Manger, P. (2005e). Pyramidal cell specialization in the occipitotemporal cortex of the Chacma baboon (Papio ursinus). Exp. Brain Res. 167, 496-503. doi: 10.1007/s00221-005-0057-3

Elston, G. N., Benavides-Piccione, R., Elston, A., DeFelipe, J., and Manger, P. (2005g). Specialization in pyramidal cell structure in the cingulate cortex of the Chacma baboon (Papio ursinus): an intracellular injection study of the posterior and anterior cingulate gyrus with comparative notes on macaque and vervet monkeys. Neurosci. Lett. 387, 130-135. doi: 10.1016/j.neulet.2005.06.010

Elston, G. N., Benavides-Piccione, R., Elston, A., DeFelipe, J., and Manger, P. (2005h). Specialization in pyramidal cell structure in the sensory-motor cortex of the vervet monkey (Cercopithecus pygerythrus). Neuroscience 134, 1057-1068. doi: 10.1016/j.neuroscience.2005.04.054

Elston, G. N., Benavides-Piccione, R., Elston, A., Manger, P., and DeFelipe, J. (2005d). Pyramidal cell specialization in the occipitotemporal cortex of the vervet monkey (Cercopithecus pygerythrus). Neuroreport 16, 967-970. doi: 10.1097/00001756-200506210-00017

Elston, G. N., Benavides-Piccione, R., Elston, A., Manger, P., and DeFelipe, J. (2005f). Regional specialization in pyramidal cell structure in the limbic cortex of the vervet monkey (Cercopithecus pygerythrus): an intracellular injection study of the anterior and posterior cingulate gyrus. Exp. Brain Res. 167, 315-323. doi: 10.1007/s00221-005-0043-9

Elston, G. N., Benavides-Piccione, R., Elston, A., Manger, P., and DeFelipe, J. (2005i). Specialization in pyramidal cell structure in the sensory-motor cortex of the Chacma baboon (Papio ursinus) with comparative notes on the macaque monkey. Anat. Rec. 286, 854-865. doi: 10.1002/ar.a.20217

Elston, G. N., Benavides-Piccione, R., Elston, A., Manger, P., and DeFelipe, J. (2011b). Pyramidal cells in prefrontal cortex: comparative observations reveal unparalleled specializations in neuronal structure among primate species. Front. Neuroanat. 5:2. doi: 10.3389/fnana.2011.00002

Elston, G. N., Benavides-Piccione, R., Elston, A., Zietsch, B., DeFelipe, J., Manger, P., et al. (2006a). Specializations of the granular prefrontal cortex of primates: implications for cognitive processing. Anat. Rec. 288A, 26-35. doi: 10.1002/ar.a.20278

Elston, G. N., and DeFelipe, J. (2002). "Spine distribution in neocortical pyramidal cells: a common organizational principle across species," in Progress in Brain Research, eds E. C. Azmitia, J. DeFelipe, E. G. Jones, P. Rakic, and C. E. Ribak (Amsterdam: Elsevier), 109-133.

Elston, G. N., DeFelipe, J., Arellano, J. I., González-Albo, M. C., and Rosa, M. G. P. (1999d). Variation in the spatial relationship between parvalbumin immunoreactive interneurones and pyramidal neurones in rat somatosensory cortex. Neuroreport 10, 2975-2979. doi: 10.1097/00001756-199909290-00019

Elston, G. N., Elston, A., Aurelio-Freire, M., Gomes Leal, W., Amaral Dias, I., Pereira, A. Jr., et al. (2006b). Specialization of pyramidal cell structure in the visual areas V1, V2 and V3 of the South American rodent, Dasyprocta primnolopha. Brain Res. 1106, 99-110. doi: 10.1016/j.brainres.2006.05.100

Elston, G. N., Elston, A., Casagrande, V. A., and Kaas, J. H. (2005c). Pyramidal neurons of granular prefrontal cortex the galago: complexity in the evolution of the psychic cell. Anat. Rec. 285, 610-618. doi: 10.1002/ar.a.20198

Elston, G. N., Elston, A., Kaas, J., and Casagrande, V. A. (2005b). Regional specialization in pyramidal cell structure in the visual cortex of the galago. an intracellular injection study with comparative notes on New World and Old World monkeys. Brain Behav. Evol. 66, 10-21. doi: 10.1159/000085044

Elston, G. N., and Garey, L. J. (2004). New Research Findings on the Anatomy of the Cerebral Cortex of Special Relevance to Anthropological Questions. Brisbane, QLD: University of Queensland Printery.

Elston, G. N., and González-Albo, M. C. (2003). Parvalbumin-, calbindin- and calretinin- immunoreactive neurons in the prefrontal cortex of the owl monkey (Aotus trivirgatus): a standardized quantitative comparison with sensory and motor cortex. Brain Behav. Evol. 62: 19-30. doi: 10.1159/000071957

Elston, G. N., and Manger, P. R. (2014). Pyramidal cells in V1 of African rodents are bigger more branched and more spiny than those in primates. Front. Neuroanat. 8:4. doi: 10.3389/fnana.2014.00004

Elston, G. N., Oga, T., and Fujita, I. (2009). Spinogenesis and pruning scales across functional hierarchies. J. Neurosci. 29, 3271-3275. doi: 10.1523/JNEUROSCI.5216-08.2009

Elston, G. N., Oga, T., Okamoto, T., and Fujita, I. (2010a). Spinogenesis and pruning from early visual onset to adulthood: an intracellular injection study of layer III pyramidal cells in the ventral visual cortical pathway of the macaque monkey. Cereb. Cortex 20, 1398-1408. doi: 10.1093/cercor/bhp203

Elston, G. N., Oga, T., Okamoto, T., and Fujita, I. (2011a). Spinogenesis and pruning in the anterior ventral inferotemporal cortex of the macaque monkey: an intracellular injection study of layer III pyramidal cells. Front. Neuroanat. 5:42. doi: 10.3389/fnana.2011.00042

Elston, G. N., Okamoto, T., Oga, T., Dornan, D., and Fujita, I. (2010b). Spinogenesis and pruning in the primary auditory cortex of the macaque monkey (Macaca fascicularis): An intracellular injection study of layer III pyramidal cells. Brain Res. 1316, 35-42. doi: 10.1016/j.brainres.2009.12.056

Elston, G. N., and Rockland, K. (2002). The pyramidal cell of the sensorimotor cortex of the macaque monkey: phenotypic variation. Cereb. Cortex 12, 1071-1078. doi: 10.1093/cercor/12.10.1071

Elston, G. N., and Rosa, M. G. P. (1997). The occipitoparietal pathway of the macaque monkey: comparison of pyramidal cell morphology in layer III of functionally related cortical visual areas. Cereb. Cortex 7, 432-452. doi: 10.1093/cercor/7.5.432

Elston, G. N., and Rosa, M. G. P. (1998). Morphological variation of layer III pyramidal neurones in the occipitotemporal pathway of the macaque monkey visual cortex. Cereb. Cortex 8, 278-294. doi: 10.1093/cercor/8.3.278

Elston, G. N., and Rosa, M. G. P. (2006). Ipsilateral corticocortical projections to the primary and middle temporal visual areas of the primate cerebral cortex: area-specific variations in the morphology of connectionally identified pyramidal cells. Eur. J. Neurosci. 23, 3337-3345. doi: 10.1111/j.1460-9568.2006. 04847.x

Elston, G. N., Tweedale, R., and Rosa, M. G. P. (1999a). Cortical integration in the visual system of the macaque monkey: large scale morphological differences of pyramidal neurones in the occipital, parietal and temporal lobes. Proc. R. Soc. Lond. Ser. B 266, 1367-1374. doi: 10.1098/rspb.1999.0789 
Elston, G. N., Tweedale, R., and Rosa, M. G. P. (1999b). Cellular heterogeneity in cerebral cortex. A study of the morphology of pyramidal neurones in visual areas of the marmoset monkey. J. Comp. Neurol. 415, 33-51.

Feldman, M. L., and Peters, A. (1979). A technique for estimating total spine numbers on Golgi-impregnated dendrites. J. Comp. Neurol. 188, 527-542. doi: $10.1002 /$ cne. 901880403

Ferster, D. (1998). A sense of direction. Nature 392, 433-434. doi: 10.1038/33005

Freire, M. A. M., Faber, J., Picanço-Diniz, C. W., Franca, J. G., and Pereira, A. (2012). Morphometric variability of nicotinamide adenine dinucleotide phosphate diaphorase neurons in the primary sensory areas of the rat. Neuroscience 205, 140-153. doi: 10.1016/j.neuroscience.2011.12.029

Freire, M. A. M., Rocha, E. G., Oliveira, J. L. F., Guimarães, J. S., Silveira, L. C. L., Elston, G. N., et al. (2010). Morphological variability of NADPH diaphorase neurons across areas V1, V2, and V3 of the common agouti. Brain Res. 1318, 52-63. doi: 10.1016/j.brainres.2009.12.045

Fujita, I., and Fujita, T. (1996). Intrinsic connections in the macaque inferior temporal cortex. J. Comp. Neurol. 368, 467-486.

Funahashi, S., and Takeda, K. (2002). Information processes in the primate prefrontal cortex in relation to working memory processes. Rev. Neurosci. 13, 313-345. doi: 10.1515/REVNEURO.2002.13.4.313

Fuster, J. M. (1997). The Prefrontal Cortex: Anatomy, Physiology, and Neuropsychology of the Frontal Lobe. Philadelphia, PA: Lippincott-Raven.

Goldman-Rakic, P. S. (1999). The "psychic" neuron of the cerebral cortex. Ann. N.Y. Acad. Sci. 868, 13-26. doi: 10.1111/j.1749-6632.1999.tb11270.x

González-Burgos, G., Barrionuevo, G., and Lewis, D. A. (2000). Horizontal synaptic connections in monkey prefrontal cortex: an in vitro electrophysiological study. Cereb. Cortex 10, 82-92. doi: 10.1093/cercor/10.1.82

Gonzalez-Burgos, G., Kroener, S., Zaitsev, A. V., Povysheva, N. V., Krimer, L. S., Barrionuevo, G., et al. (2008). Functional maturation of excitatory synapses in layer 3 pyramidal neurons during postnatal development of the primate prefrontal cortex. Cereb. Cortex 18, 626-637. doi: 10.1093/cercor/bhm095

Govek, E. E., Hatten, M. E., and Van Aelst, L. (2011). The role of Rho GTPase proteins in CNS neuronal migration. Dev. Neurobiol. 71, 528-553. doi: 10.1002/dneu.20850

Granger, B., Tekaia, F., Le Sourd, A. M., Rakic, P., and Bourgeois, J. P. (1995). Tempo of neurogenesis and synaptogenesis in the primate cingulate mesocortex: comparison with the neocortex. J. Comp. Neurol. 360, 363-376. doi: $10.1002 /$ cne. 903600212

Guillery, R. W. (2005). Is postnatal neocortical maturation hierarchical? Trends Neurosci. 28, 512-517. doi: 10.1016/j.tins.2005.08.006

Hof, P. R., and Morrison, J. H. (1995). Neurofilament protein defines regional patterns of cortical organization in the macaque monkey visual system: a quantitative immunohistochemical analysis. J. Comp. Neurol. 352, 161-186. doi: $10.1002 /$ cne. 903520202

Hof, P. R., and Nimchinsky, E. A. (1992). Regional distribution of neurofilament and calcium-binding proteins in the cingulate cortex of the macaque monkey. Cereb. Cortex 2, 456-467. doi: 10.1093/cercor/2.6.456

Huttenlocher, P. R. (1979). Synaptic density in human frontal cortex- developmental changes and effects of aging. Brain Res. 163, 195-205. doi: 10.1016/00068993(79)90349-4

Huttenlocher, P. R. (1990). Morphometric study of human cerebral cortex development. Neuropsychologia 28, 517-527. doi: 10.1016/0028-3932(90)90031-I

Huttenlocher, P. R., and Dabholkar, A. S. (1997). Regional differences in synaptogenesis in human cerebral cortex. J. Comp. Neurol. 387, 167-178.

Jacobs, B., Driscoll, L., and Schall, M. (1997). Life-span dendritic and spine changes in areas 10 and 18 of human cortex: a quantitative Golgi study. J. Comp. Neurol. $386,661-680$.

Jacobs, B., Johnson, N. L., Wahl, D., Schall, M., Maseko, B. C., Lewandowski, A., et al. (2014). Comparative neuronal morphology of the cerebellar cortex in afrotherians, carnivores, cetartiodactyls, and primates. Front. Neuroanat. 8:24. doi: 10.3389/fnana.2014.00024

Jacobs, B., Schall, M., Prather, M., Kapler, E., Driscoll, L., Baca, S., et al. (2001). Regional dendritic and spine variation in human cerebral cortex: a quantitative study. Cereb. Cortex 11, 558-571. doi: 10.1093/cercor/11.6.558

Jacobs, B., and Scheibel, A. B. (2002). "Regional dendritic variation in primate cortical pyramidal cells," in Cortical Areas: Unity And Diversity, eds A. Schüz and R. Miller (London: Taylor and Francis), 111-131. doi: 10.1201/9780203299296.pt2

Jones, E. G. (2009). The origins of cortical interneurons: mouse versus monkey and human. Cereb. Cortex 19, 1953-1956. doi: 10.1093/cercor/bhp088
Jones, T. A., Kleim, J. A., and Greenough, W. T. (1996). Synaptogenesis and dendritic growth in cortex opposite unilateral sensorimotor cortex damage in adult rats: a quantitative electron microscopic examination. Brain Res. 733, 142-148. doi: 10.1016/0006-8993(96)00792-5

Jones, T. A., and Schallert, T. (1992). Overgrowth and pruning of dendrites in adult rats recovering from neocortical damage. Brain Res. 581, 156-160. doi: 10.1016/0006-8993(92)90356-E

Kaas, J. H., Krubitzer, L. A., Chino, Y. M., Langston, A. L., Polley, E. H., and Blair, N. (1990). Reorganization of retinotopic cortical maps in adult mammals after lesions of the retina. Science 248, 229-231. doi: 10.1126/science.2326637

Kasper, E. M., Larkman, A. U., Lübke, J., and Blakemore, C. (1994). Pyramidal neurons in layer 5 of the rat visual cortex. II. Development of electrophysiological properties. J. Comp. Neurol. 339, 475-494. doi: 10.1002/cne.903390403

Keck, T., Mrsic-Flogel, T. D., Vaz Afonso, M., Eysel, U. T., Bonhoeffer, T., and Hübener, M. (2008). Massive restructuring of neuronal circuits during functional reorganization of adult visual cortex. Nat. Neurosci. 11, 1162-1167. doi: $10.1038 / \mathrm{nn} .2181$

Kiorpes, L., and Movshon, J. A. (2003). "Neural limitations on visual development in primates," in The Visual Neurosciences, eds L. M. Chalupa and J. S.Werner (New York, NY: The MIT Press), 159-173.

Kiorpes, L., and Movshon, J. A. (2004). Development of sensitivity to visual motion in macaque monkeys. Vis. Neurosci. 21, 851-859. doi: $10.1017 /$ S0952523804216054

Kiorpes, L., Price, T., Hall-Haro, C., and Movshon, J. A. (2012). Development of sensitivity to global form and motion in macaque monkeys (Macaca nemestrina). Vision Res. 63, 34-42. doi: 10.1016/j.visres.2012.04.018

Knott, G., and Holtmaat, A. (2008). Dendritic spine plasticity-current understanding from in vivo studies. Brain Res. Rev. 58, 282-289. doi: 10.1016/j.brainresrev.2008.01.002

Knott, G. W., Holtmaat, A., Wilbrecht, L., Welker, E., and Svoboda, K. (2006). Spine growth precedes synapse formation in the adult neocortex in vivo. Nat. Neurosci. 9, 1117-1124. doi: 10.1038/nn1747

Koenderink, M. J., Uylings, H. B., and Mrzljak, L. (1994). Postnatal maturation of the layer III pyramidal neurons in the human prefrontal cortex: a quantitative Golgi analysis. Brain Res. 653, 173-182. doi: 10.1016/0006-8993(94)90387-5

Kondo, H. T., Hashikawa, T., Tanaka, K., and Jones, E. G. (1994). Neurochemical gradient along the monkey occipito-temporal cortical pathway. Neuroreport 5 , 613-616. doi: 10.1097/00001756-199401000-00020

Kritzer, M. F., Cowey, A., and Somogyi, P. (1992). Patterns of inter- and intralaminar GABAergic connections distinguish striate (V1) and extrastriate (V2, V4) visual cortices and their functionally specialized subdivisions in the rhesus monkeys. J. Neurosci. 12, 4545-4564.

Li, D.-P., Hagan, M. A., and Kiorpes, L. (2013). Linking structure and function: development of lateral spatial interactions in macaque monkeys. Vis. Neurosci. 30, 263-270. doi: 10.1017/S0952523813000394

Livingstone, M. S. (1998). Mechanisms of direction selectivity in macaque V1. Neuron 20, 509-526. doi: 10.1016/S0896-6273(00)80991-5

London, M., and Häusser, M. (2005). Dendritic computation. Annu. Rev. Neurosci. 28, 503-532. doi: 10.1146/annurev.neuro.28.061604.135703

Luebke, J. I., Medalla, M., Amatrudo, J. M., Weaver, C. M., Crimins, J. L., Hunt, B., et al. (2013). Age-related changes to layer 3 pyramidal cells in the rhesus monkey visual cortex. Cereb. Cortex. doi: 10.1093/cercor/bht336. [Epub ahead of print].

Lund, J. S., and Holbach, S. M. (1991). Postnatal development of thalamic recipient neurons in the striate cortex: I. comparison of spine acquisition and dendrite growth of layer 4C alpha and beta spiny stellate neurons. J. Comp. Neurol. 309, 115-128. doi: 10.1002/cne.903090108

Lund, J. S., Yoshioka, T., and Levitt, J. B. (1993). Comparison of intrinsic connectivity in different areas of macaque monkey cerebral cortex. Cereb. Cortex 3 , 148-162. doi: 10.1093/cercor/3.2.148

Maruko, I., Zhang, B., Tao, X., Tong, J., Smith, E. L., and Chino, Y. M. (2008). Postnatal development of disparity sensitivity in visual area 2 (V2) of macaque monkeys. J. Neurophysiol. 100, 2486-2495. doi: 10.1152/jn.90397.2008

Maruyama, A., Ishikawa, A., Hosoyama, D., Yoshimura, Y., Tamura, H., Sato, H., et al. (2007). Development of membrane properties of layer III pyramidal neurons in macaque visual cortical areas V1 and TE. Soc. Neurosci. Abstr. 279, 10.

Mates, S. L., and Lund, J. S. (1983a). Neuronal composition and development in lamina 4C of monkey striate cortex. J. Comp. Neurol. 221, 60-90. doi: $10.1002 /$ cne. 902210106 
Mates, S. L., and Lund, J. S. (1983b). Spine formation and maturation of type 1 synapses on spiny stellate neurons in primate visual cortex. J. Comp. Neurol. 221, 91-97. doi: 10.1002/cne.902210107

Matsubara, J. A., Chase, R., and Thejomayen, M. (1996). Comparative morphology of three types of projection-identified pyramidal neurons in the superficial layers of cat visual cortex. J. Comp. Neurol. 366, 93-108.

Matsuzaki, M., Honkura, N., Ellis-Davis, G. C., and Kasai, H. (2004). Structural basis of long-term potentiation in single dendritic spines. Nature 429, 761-766. doi: 10.1038/nature02617

McCormick, D. A., and Prince, D. A. (1987). Post-natal development of electrophysiological properties of rat cerebral cortical pyramidal neurones. J. Physiol. (Lond.) 393, 743-762.

Meissirel, C., Dehay, C., Berland, M., and Kennedy, H. (1991). Segregation of callosal and association pathways during development in the visual cortex of the primate. J. Neurosci. 11, 3297-3316.

Melchitzky, D. S., González-Burgos, G., Barrionuevo, G., and Lewis, D. A. (2001). Synaptic targets of the intrinsic axon collaterals of supragranular pyramidal neurons in monkey prefrontal cortex. J. Comp. Neurol. 430, 209-221. doi: 10.10 02/1096-9861(20010205)430:2\%3C209::AID-CNE1026\%3E3.0.CO;2-\%23

Melchitzky, D. S., Sesack, S. R., Pucak, M. L., and Lewis, D. A. (1998). Synaptic targets of pyramidal neurons providing intrinsic horizontal connections in monkey prefrontal cortex. J. Comp. Neurol. 390, 211-224.

Metherate, R., and Aramakis, V. B. (1999). Intrinsic electrophysiology of neurons in thalamorecipient layers of developing rat auditory cortex. Brain Res. Dev. Brain Res. 115, 131-144. doi: 10.1016/S0165-3806(99)00058-9

Miller, E. K., and Cohen, J. D. (2001). An integrative theory of prefrontal cortex. Annu. Rev. Neurosci. 24, 167-202. doi: 10.1146/annurev.neuro.24.1.167

Movshon, J. A., Kiorpes, L., Cavanaugh, J. R., and Hawken, M. J. (1999). Receptive field properties and surround interactions in V1 neurons in infant macaque monkeys. Soc. Neurosci. Abstr. 25, 1048.

Movshon, J. A., Kiorpes, L., Cavanaugh, J. R., and Hawken, M. J. (2000). Developmental reorganization of receptive field surrounds in V1 neurons in infant macaque monkeys. Invest. Ophthalmol. Vis. Sci. 41, 333.

Murayama, Y., Fujita, I., and Kato, M. (1997). Contrasting forms of synaptic plasticity in monkey inferotemporal and primary visual cortices. Neuroreport 8, 1503-1508. doi: 10.1097/00001756-199704140-00036

Nakajima, K. (2007). Control of tangential/non-radial migration of neurons in the developing cerebral cortex. Neurochem. Int. 51, 121-131. doi: 10.1016/j.neuint.2007.05.006

Oga, T., Aoi, H., Sasaki, T., Fujita, I., and Ichinohe, N. (2013). Postnatal development of layer III pyramidal cells in the primary visual, inferior temporal, and prefrontal cortices of the marmoset. Front. Neural Circuits 7:31. doi: 10.3389/fncir.2013.00031

O'Kusky, J., and Colonnier, M. (1982). Postnatal changes in the number of neurons and synapses in the visual cortex (area 17) of the macaque monkey: a stereological analysis in normal and monocularly deprived animals. J. Comp. Neurol. 210, 291-306. doi: 10.1002/cne.902100308

Oswald, A.-M., and Reyes, A. D. (2008). Maturation of intrinsic and synaptic properties of layer $2 / 3$ pyramidal neurons in mouse auditory cortex. J. Neurophysiol. 99, 2998-3008. doi: 10.1152/jn.01160.2007

Petanjek, Z., Judas, M., Kostovic, I., and Uylings, H. B. M. (2008). Lifespan alterations of basal dendritic trees of pyramidal neurons in the human prefrontal cortex: a layer-specific pattern. Cereb. Cortex 18, 915-929. doi: 10.1093/cercor/bhm 124

Petralia, R. S., Wang, Y. X., and Wenthold, R. J. (1994b). The NMDA receptor subunits NR2A and NR2B show histological and ultrastructural localization patterns similar to those of NR1. J. Neurosci. 14, 6102-6120.

Petralia, R. S., Wang, Y.-X., and Wenthold, R. J. (1994c). Histological and ultrastructural localization of kainate receptor subunits, KA2 and GluR6/7, in the rat nervous system using selective antipeptide antibodies. J. Comp. Neurol. 349, 85-110. doi: 10.1002/cne.903490107

Petralia, R. S., Yokotani, N., and Wenthold, R. J. (1994a). Light and electron microscope distribution of the NMDA receptor subunit NMDAR1 in the rat nervous system using a selective antipeptide antibody. J. Neurosci. 14, 667-696.

Pettigrew, J. D. (1974). The effect of visual experience on the development of stimulus specificity by kitten cortical neurones. J. Physiol. (Lond.) 237, 49-74.

Poirazi, P., and Mel, B. W. (2001). Impact of active dendrites and structural plasticity on the memory capacity of neural tissue. Neuron 29, 779-796. doi: 10.1016/S0896-6273(01)00252-5
Preuss, T. M. (2000). "What's human about the human brain?", in The New Cognitive Neurosciences, ed M. S. Gazzaniga (Cambridge, MA: MIT Press), 1219-1234.

Preuss, T. M., and Goldman-Rakic, P. S. (1991). Architectonics of the parietal and temporal association cortex in the strepsirhine primate Galago compared to the anthropoid Macaca. J. Comp. Neurol. 310, 475-506. doi: 10.1002/cne.903100403

Rakic, P. (1990). Principles of neuronal cell migration. Experientia 46, 882-891. doi: 10.1007/BF01939380

Rakic, P. (2009). Evolution of the neocortex: a perspective from developmental biology. Nat. Rev. Neurosci. 10, 724-735. doi: 10.1038/nrn2719

Rakic, P., Bourgeois, J.-P., Eckenhoff, M. F., Zecevic, N., and Goldman-Rakic, P. S. (1986). Concurrent overproduction of synapses in diverse regions of the primate cerebral cortex. Science 232, 232-235. doi: 10.1126/science.3952506

Rockland, K. S., and Lund, J. S. (1982). Widespread periodic intrinsic connections in the tree shrew visual cortex. Science 215, 1532-1534. doi: 10.1126/science.7063863

Rockland, K. S., and Lund, J. S. (1983). Intrinsic laminar lattice connections in primate visual cortex. J. Comp. Neurol. 216, 303-318. doi: 10.1002/cne.902160307

Rodman, H. R. (1994). Development of inferior temporal cortex in monkey. Cereb. Cortex 5, 484-498. doi: 10.1093/cercor/4.5.484

Rodman, H. R., and Consuelos, M. J. (1994). Cortical projections to anterior inferior temporal cortical cortex in infant macaque monkeys. Vis. Neurosci. 11, 119-133. doi: 10.1017/S0952523800011160

Rodman, H. R., Scalaidhe, S. P., and Gross, G. C. (1993). Response properties of neurons in temporal cortical visual areas of infant monkeys. J. Neurophysiol. 70, 1115-1136.

Romand, S., Wang, Y., Toledo-Rodriguez, M., and Markram, H. (2011). Morphological development of thick-tufted layer V pyramidal cells in the rat smoatosensory cortex. Front. Neuroanat. 5:5. doi: 10.3389/fnana.2011.00005

Sala, C., Cambianica, I., and Rossi, F. (2008). Molecular mechanisms of dendritic spine development and maintenance. Acta Neurobiol. Exp. (Wars) 68, 289-304.

Sasaki, T., Aoi, H., Oga, T., Fujita, I., and Ichinohe, N. (2014). Postnatal development of dendritic structure of layer III pyramidal neurons in the medial prefrontal cortices of the marmoset. Brain. Struct. Funct. [Epub ahead of print].

Schmid, L. M., Rosa, M. G. P., Calford, M. B., and Ambler, J. S. (1996). Visuotopic reorganisation in the primary visual cortex of adult cats following monocular and binocular retinal lesions. Cereb. Cortex 6, 388-405. doi: 10.1093/cercor/6.3.388

Schwartz, M. L., and Goldman-Rakic, P. (1990). Development and plasticity of the primate cerebral cortex. Clin. Perinatol. 17, 83-102.

Schwartz, M. L., and Goldman-Rakic, P. S. (1991). Prenatal specification of callosal connections in rhesus monkey. J. Comp. Neurol. 307, 142-162. doi: $10.1002 /$ cne. 903070113

Sholl, D. A. (1955). The surface area of cortical neurons. J. Anat. 89, 571-572.

Somogyi, P., Tamas, G., Lujan, R., and Buhl, E. H. (1998). Salient features of synaptic organisation in the cerebral cortex. Brain Res. Brain Res. Rev. 26, 113-135. doi: 10.1016/S0165-0173(97)00061-1

Spruston, N. (2008). Pyramidal neurons: dendritic structure and synaptic integration. Nat. Rev. Neurosci. 9, 206-221. doi: 10.1038/nrn2286

Tanigawa, H., Fujita, I., Kato, M., and Ojima, H. (1998). Distribution, morphology, and $\gamma$-aminobutyric acid immunoreactivity of horizontally projecting neurons in the inferior temporal cortex. J. Comp. Neurol. 401, 129-143.

Tanigawa, H., Wang, Q.-X., and Fujita, I. (2005). Organization of horizontal axons in the inferior temporal cortex and primary visual cortex of the macaque monkey. Cereb. Cortex 15, 1887-1899. doi: 10.1093/cercor/bhi067

Taylor, W. R., He, S., Levick, W. R., and Vaney, D. I. (2000). Dendritic computation of direction selectivity by retinal ganglion cells. Science 289, 2347-2350. doi: 10.1126/science.289.5488.2347

Taylor, W. R., and Vaney, D. I. (2002). Diverse synaptic mechanisms generate direction selectivity in the rabbit retina. J. Neurosci. 22, 7712-7720.

Tieman, S. B., and Hirsch, H. V. B. (1982). Exposure to lines of only one orientation modifies dendritic morphology of cells in visual cortex of the cat. J. Comp. Neurol. 211, 353-362. doi: 10.1002/cne.902110403

Trachtenberg, J. T., Chen, B. E., Knott, G. W., Feng, G. P., Sanes, J. R., Welker, E., et al. (2002). Long-term in vivo imaging of experience-dependent synaptic plasticity in adult cortex. Nature 420, 788-794. doi: 10.1038/nature01273

Travis, K., Ford, K., and Jacobs, B. (2005). Regional dendritic variation in neonatal human cortex: a quantitative Golgi study. Dev. Neurosci. 27, 277-287. doi: $10.1159 / 000086707$ 
Valverde, F. (1967). Apical dendritic spines of the visual cortex and light deprivation in the mouse. Exp. Brain Res. 3, 337-352. doi: 10.1007/BF00237559

Vaney, D. I., Sivyer, B., and Taylor, W. R. (2012). Direction selectivity in the retina: symmetry and asymmetry in structure and function. Nat. Rev. Neurosci. 13, 194-208. doi: $10.1038 / \mathrm{nrn} 3165$

Vercelli, A., and Innocenti, G. M. (1993). Morphology of visual callosal neurons with different locations, contralateral targets or patterns of development. Exp. Brain Res. 94, 393-404. doi: 10.1007/BF00230198

Wang, Q. W., Tanigawa, H., and Fujita, I. (1998). Postnatal development of horizontal axons in the inferior temporal and primary visual cortices in the monkey. Soc. Neurosci. Abstr. 24, 900.

Webster, M. J., Bachevalier, J., and Ungerleider, L. G. (1994). Connections of inferior temporal areas TEO and TE with parietal and frontal cortex in macaque monkeys. Cereb. Cortex 4, 470-483. doi: 10.1093/cercor/4.5.470

Webster, M. J., Bachevalier, J., and Ungerleider, L. G. (1995). Transient subcortical connections of inferior temporal areas TEO and TE in infant macaque monkeys. J. Comp. Neurol. 352, 213-226. doi: 10.1002/cne.903520205

Webster, M. J., Ungerleider, L. G., and Bachevalier, J. (1991). Connections of inferior temporal areas TE and TEO with medial temporal-lobe structures in infant and adult monkeys. J. Neurosci. 11, 1095-1116.

Yáñez, I. B., Muñoz, A., Contreras, J., Gonzalez, J., Rodriguez-Veiga, E., and DeFelipe, J. (2005). Double bouquet cell in the human cerebral cortex and a comparison with other mammals. J. Comp. Neurol. 486, 344-360. doi: $10.1002 /$ cne.20533

Zecevic, N., and Rakic, P. (1991). Synaptogenesis in monkey somatosensory cortex. Cereb. Cortex 1, 510-523. doi: 10.1093/cercor/1.6.510

Zhang, B., Smith, E. L. R., and Chino, Y. M. (2008). Postnatal development of onset transient responses in macaque V1 and V2 neurons. J. Neurophysiol. 100, 1476-1487. doi: 10.1152/jn.90446.2008
Zhang, B., Tao, X., Shen, G., Smith, E. R., Ohzawa, I., and Chino, Y. M. (2013). Receptive-field subfields of $\mathrm{V} 2$ neurons in macaque monkeys are adult-like near birth. J. Neurosci. 33, 2639-2649. doi: 10.1523/JNEUROSCI.4377-12.2013

Zhang, Z. W. (2004). Maturation of layer V pyramidal neurons in the rat prefrontal cortex: intrinsic properties and synaptic function. J. Neurophysiol. 91, 1171-1182. doi: 10.1152/jn.00855.2003

Zheng, J., Zhang, B., Bi, H., Maruko, I., Watanabe, I., Nakatsuka, C., et al. (2007). Development of temporal response properties and contrast sensitivity of V1 and V2 neurons in macaque monkeys. J. Neurophysiol. 97, 3905-3916. doi: $10.1152 /$ jn. 01320.2006

Zimmermann, R. R. (1961). Analysis of discrimination learning capacities in the infant Rhesus monkey. J. Comp. Physiol. Psychol. 54, 1-10. doi: $10.1037 / \mathrm{h} 0042320$

Conflict of Interest Statement: The authors declare that the research was conducted in the absence of any commercial or financial relationships that could be construed as a potential conflict of interest.

Received: 01 June 2014; accepted: 22 July 2014; published online: 12 August 2014. Citation: Elston GN and Fujita I (2014) Pyramidal cell development: postnatal spinogenesis, dendritic growth, axon growth, and electrophysiology. Front. Neuroanat. 8:78. doi: 10.3389/fnana.2014.00078

This article was submitted to the journal Frontiers in Neuroanatomy.

Copyright () 2014 Elston and Fujita. This is an open-access article distributed under the terms of the Creative Commons Attribution License (CC BY). The use, distribution or reproduction in other forums is permitted, provided the original author(s) or licensor are credited and that the original publication in this journal is cited, in accordance with accepted academic practice. No use, distribution or reproduction is permitted which does not comply with these terms. 